NBER WORKING PAPER SERIES

\title{
CLIMATE CHANGE, OPERATING FLEXIBILITY AND CORPORATE INVESTMENT DECISIONS
}

\author{
Chen Lin \\ Thomas Schmid \\ Michael S. Weisbach \\ Working Paper 26441 \\ http://www.nber.org/papers/w26441 \\ NATIONAL BUREAU OF ECONOMIC RESEARCH \\ 1050 Massachusetts Avenue \\ Cambridge, MA 02138 \\ November 2019
}

We are very grateful to David Weisbach, Hayong Yun, seminar participants at University of Chicago, the Shanghai Advanced Institute of Finance, the Shanghai University of Finance and Economics, and conference participants at the 2018 Summer Finance and Accounting Conference in Jerusalem and the 2019 University of Oklahoma Energy and Commodities Finance Research Conference for helpful suggestions. The views expressed herein are those of the authors and do not necessarily reflect the views of the National Bureau of Economic Research.

NBER working papers are circulated for discussion and comment purposes. They have not been peer-reviewed or been subject to the review by the NBER Board of Directors that accompanies official NBER publications.

(C) 2019 by Chen Lin, Thomas Schmid, and Michael S. Weisbach. All rights reserved. Short sections of text, not to exceed two paragraphs, may be quoted without explicit permission provided that full credit, including (C) notice, is given to the source. 
Climate Change, Operating Flexibility and Corporate Investment Decisions

Chen Lin, Thomas Schmid, and Michael S. Weisbach

NBER Working Paper No. 26441

November 2019

JEL No. G30,G31

\begin{abstract} firms' behavior.

Chen Lin

Faculty of Business and Economics

The University of Hong Kong

Hong Kong

chenlin1@hku.hk

Thomas Schmid

Faculty of Business and Economics

University of Hong Kong

Hong Kong

schmid@hku.hk

Michael S. Weisbach

Department of Finance

Fisher College of Business

Ohio State University

2100 Neil Ave.

Columbus, $\mathrm{OH} 43210$

and NBER

weisbach.2@osu.edu
\end{abstract}

Extreme temperatures lead to large fluctuations in electricity demand and wholesale prices of electricity, which in turn affects the optimal production process for firms to use. Using a large international sample of planned power plant projects, we measure the way that electric utilities' investment decisions depend on the frequency of extreme temperatures. We find that they invest more in regions with more extreme temperatures. These investments are mostly in flexible gas and oil-fired power plants that can easily adjust their output, to improve their operating flexibility. Our results suggest that climate change is becoming a meaningful factor affecting 
U.S. Midwest Freezes, Australia Burns: This is the Age of Weather Extremes

NY Times, January 29, 2019

Companies See Climate Change Hitting Their Bottom Lines in the Next 5 Years NY Times, June 4, 2019

Extreme Weather Sends Energy Demand Growth to 9-Year High

Financial Times, June 12, 2019

\section{Introduction}

The G20 recently called climate change "one of the greatest challenges of our time". More federal money was spent on the consequences of extreme weather during 2012 than on education or transportation; globally, the economic losses related to weather events such as prolonged periods of drought, heat waves, cold snaps, and more frequent natural hazards like tornados amounted to about $\$ 150$ billion. ${ }^{1}$ Increasing temperatures and more extreme weather conditions in many regions of the world will lead to dramatic changes in society and the economy, and we are only beginning to understand the nature of these changes.

This paper investigates how firms respond to more extreme temperatures through investments and changes to their asset structure. We focus on one industry which is meaningfully affected by weather changes: electricity-producing firms. More extreme temperatures lead to changes in electricity demand and the wholesale price of electricity, which in turn affects the optimal production process for firms to use. Using the Platts World Electric Power Plant database that contains detailed information about plant-level investments around the world, we consider a sample of 273 publicly traded electricity-generating firms which are active in 43 deregulated regions with wholesale markets for electricity between 2000 and 2016. These firms operate 37,965 power plants, and have plans to construct 4,425 new plants. We evaluate the extent to which their investment decisions depend on the frequency of extremely hot or cold temperatures.

Our focus on asset-level data to analyze investment decisions has at least three advantages relative to accounting-based measures of investment such as Capital Expenditures. First, our data cover early-stage

\footnotetext{
${ }^{1}$ Cf. Allianz (2013), p. 7.
} 
power plant projects at the planning-stage, so we know exactly when each firm makes its investment decision. Second, we know the exact location of the planned plant. We use this locational information to identify the effect of local changes of weather conditions on investment. Information on differences in weather changes across regions allows us to exploit variations in investment decisions across different regions within firms. Third, we observe the type of the planned power plants since our data provides detailed information on their production technologies. These data allow us to ascertain the flexibility of any particular power plant.

To measure extreme weather conditions, we calculate the frequency of days with extremely hot or cold temperatures in a region (i.e., an electricity wholesale market) and year, using temperature data for individual weather stations from the Global Historical Climatology Network (GHCN). To determine whether a particular temperature is unusual, we compare it to the distribution of temperatures in the same region in the base period from 1951 to 1980 (Hansen et al., 2012). A day in our sample period 2000 to 2016 is then classified as extreme if it would belong to the hottest or coldest one percent of days in the base period ( 0.5 and five percent are used as robustness tests). By this classification scheme, the expected value for this variable would be two percent if weather conditions did not change between the base period and our sample period. Empirically, we find that about 3.4 percent of all days in the sample period are classified as extremely hot or cold, which represents a substantial increase relative to the base period.

Theoretically, one potential consequence of an increase in extreme weather conditions could be more volatile temperatures. More volatile temperatures can then lead to more volatile electricity demand because outside temperatures are key drivers of (residential) electricity demand due to heating and cooling demands (Perez-Gonzalez and Yun, 2013). Because electricity storage is not possible in economically meaningful terms, changes in demand typically lead to electricity price changes. For this reason, electricity price volatility is likely to increase.

More volatile electricity prices that occur because of these extreme temperatures make operating flexibility in the form of flexible gas or oil-fired power plants more attractive for energy firms for two reasons. First, flexible methods of electricity generation, such as gas-fired power plants, can adjust their 
output quickly and at low cost when electricity prices change. In contrast, inflexible plants, such as coalfired plants, have high fixed cost and require long time to adjust production volume. Consider, for example, the 2019 heat wave in Texas, during which there was a record high demand and electricity prices. ${ }^{2}$ More flexible methods of production would be valuable to electricity producers in times of extreme weather to cope with the demand and take advantage of the high prices. Second, more supply flexibility is needed to cope with higher demand volatility and to avoid system breakdowns ("blackouts"). For these two reasons, when electricity demand and prices become more volatile, we hypothesize that firms invest more in flexible production to increase their operating flexibility.

We find that utilities increase their investments in flexible power plants in regions in which weather conditions are becoming more extreme. When we exploit variations of weather conditions across regions and time, the estimates imply that the planned capacity of flexible power plants, scaled by the total existing capacity, increases by 0.8 percentage points if one percent more days have extreme weather. The model further predicts that a one-standard deviation increase in the fraction of extreme days increases flexible investment by about two percentage points, which corresponds to a relative increase of 25 percent. If we focus exclusively on the variation of weather conditions over time in a particular market region, the point estimates are slightly smaller and imply that a one-standard deviation increase in the fraction of extreme days increases investments in flexible plants by 1.2 percentage points. The outcome is similar if we only focus on variations across regions within a firm by including firm times year fixed effects. The inclusion of control variables such as regional GDP or firm-level factors (which are already controlled for in the model with firm times year fixed effects) has no material impact on the results.

For investments in inflexible plants, which have relatively high fixed costs, the uncertainty about the exact degree of future weather changes and regulators' responses to climate change may play an important role. In line with results for political uncertainty (Julio and Yook, 2012; Gulen and Ion, 2016) or theoretical models which assume irreversible investments (McDonald and Siegel, 1986; Dixit and Pindyck,

${ }^{2}$ https://www.reuters.com/article/texas-power-demand/texas-power-prices-jump-to-record-high-as-heat-bakes-stateidUSL2N25W0AB 
$1994)^{3}$, higher uncertainty could cause firms to delay the construction of power plants, especially inflexible plants with high fixed cost. For renewables, it is well possible that firms want to increase their investments in wind and solar plants to reduce their $\mathrm{CO} 2$ emissions in regions in which climate change is more severe. In these regions, public pressure is likely to be especially high on firms to act in an environmentally friendly manner. There is no clear prediction for total investments as the effect of pressure to reduce emissions on overall investment in power plants is the sum of its impact on different types of power plants, each of which is likely to be different from one another.

We find no evidence of any effect of extreme weather conditions on investments in inflexible plants. For renewable plants, we find a negative point estimate, which is not statistically significantly different from zero. The results suggest that neither investments in inflexible nor renewable plants are materially affected by extreme weather. Given the strong positive impact on flexible investments and the non-effects for other types of plants, it is not surprising that the aggregate effect on total investments is positive as well.

We conduct multiple robustness tests for our main result that more extreme weather conditions increase planned investments in flexible generation. We document that this result is not driven by firms that have high market power or by differences in gas prices or spark spreads (i.e., electricity price minus cost of natural gas). We also subsequently exclude all single markets to make sure that we document a general effect which is not driven by one particular region. Furthermore, we use alternative ways to measure extreme weather conditions, alternative definitions of planned investments (e.g., based on the number instead of the capacity of plants), alternative fixed effects or clustering of standard errors, and additional control variables which capture capital market development, electricity market characteristics, or other aspects of a firm's production assets. All of these tests confirm our main findings.

So far, we have argued that firms invest in flexible generation because more frequent extreme weather conditions increase the volatility of electricity demand and prices, which would lead firms to favor

\footnotetext{
${ }^{3}$ However, models that consider time-to-build, which is typically years for power plants, find that the uncertaintyinvestment relation is considerably weaker or, in extreme cases, even reversed (Bar-Ilan and Strange, 1996).
} 
production techniques for which quantities can be adjusted quickly and at low cost. To test this possible mechanism, we start by examining the way in which other weather characteristics change when the weather becomes more extreme. Our estimates indicate that both cooling and heating degree days increase, which suggests more electricity is needed for cooling and heating. At the same time, daily average temperatures become more volatile. These changing weather characteristics affect electricity demand. While we find clear evidence that residential demand increases, the effect for total demand is positive but not statistically significant. The volatility of electricity demand increases substantially in regions in which the weather becomes more extreme.

Not surprisingly, these demand-side changes have an effect on wholesale prices for electricity. Our price measures are based on hourly electricity prices in the different wholesale markets. For the price level, we find positive point estimates, but they are marginally insignificant, which is in line with the result that total demand did not increase significantly. Consistent with more volatile electricity demand, we find evidence of a substantial increase in the price volatility. The point estimates suggest that a one-standard deviation increase of the frequency of extremely hot or cold days lead to an electricity price volatility increase of about 15 to 20 percent. These results suggest that more extreme weather mainly affects the volatility of electricity prices, but not necessarily their level.

When we use electricity price volatility directly as an independent variable in models explaining flexible investments, we find estimates that are consistent with those discussed above: higher price volatility increases planned investments in flexible plants. Thus, higher electricity price volatility due to more extreme weather conditions is a likely channel for firms' increases in planned investments in flexible generation. We find no evidence that alternative mechanisms like more stringent environmental regulations or differences in the penetration of renewables play a substantial role.

Next, we focus on the question whether extreme weather realizations today have predictive power for future weather conditions. To this point we have argued that firms increase investments in flexible generation when the weather becomes more extreme to increase their future operating flexibility. The logic of this argument depends on more extreme weather conditions today being associated with more extreme 
weather conditions in the future when the newly constructed plants go online. To investigate the predictive power of current extreme weather realizations for the future, we calibrate a forecasting model with a marketspecific linear trend function and include or exclude the more recent extreme weather realization. We find that including the most recent extreme weather realization in the calibration reduces the forecast error by five to ten percent. Thus, adjusting investment plans based on realizations of extreme weather seems meaningful because these realizations help to update predictions about future weather conditions.

We also investigate the role of operating flexibility in more detail. We find that firms increase their operating flexibility substantially in regions in which weather conditions become more extreme. This result holds regardless of whether we use the planned change in flexible production capacity, or the actual change in flexible production capacity over the next four years. When we analyze which firms invest in flexible power plants as response to more extremely hot or cold days, we find that the building-up of flexible production capacity is stronger in firms with a low level of existing operating flexibility. These results suggest that firms react to more extreme weather conditions by adjusting their production portfolio towards more operating flexibility.

One factor that could reduce the impact of extreme weather is more precise weather forecasting. If market operators and firms know well in advance that temperatures and demand will change, they can prepare and plan production adjustments, which would reduce the importance of operating flexibility. Using detailed weather forecasts data from multiple providers, we find that the impact of extreme weather on flexible investments is more pronounced if the average 3-day temperature forecast error is high and if the forecasts of different forecast providers are more dispersed.

Although this study focuses exclusively on energy utilities, our results potentially have implications for other industries as well. While the nature of the impact of extreme weather conditions is likely to vary by industry and is undoubtedly different from the electricity generating industry we study here because of the unique relation between energy demand and weather, operating flexibility will likely play a key role for many firms, not only for energy utilities, to react to new climatic conditions. Firms from many industries 
will have to cope with adjustments of their production process, ${ }^{4}$ disruptions to their supply chains, ${ }^{5}$ less predictable consumer demand, ${ }^{6}$ shifts of consumer preferences, ${ }^{7}$ or new regulations ${ }^{8}$ as result of more extreme weather conditions. The real effects of climate change on businesses in many industries are likely to be consequential and are not well understood at this point.

Our analysis extends the literature in several ways. First, we provide asset-level evidence on firms' investment decisions. In particular, this study is related to prior work which investigates how investment is linked to uncertainty in general (e.g., Abel, 1983; Dixit and Pindyck, 1994; Bloom, 2009), political uncertainty (e.g., Julio and Yook, 2012; Gulen and Ion, 2016), economic volatility (e.g. Giroud and Mueller, 2019), or product market characteristics (e.g., Dixit, 1980; Akdogu and MacKay, 2008). By doing so, our paper also adds to the broader literature of determinants of corporate investment (e.g., Gan, 2007a,b; Billett, Garfinkel, and Jiang, 2011; Bolton, Chen, and Wang, 2013; Giroud, 2013; Harford and Uysal, 2014). We extend this literature by showing that weather conditions as a macro factor can have a strong explanatory power for firm-level investments. By focusing on the establishment network of the firms and within-firm investment decisions, our paper also contributes to the recent literature on firm networks and investments (e.g. Giroud and Mueller, 2019). Analyzing how firms' investment decisions affect their operating flexibility adds to the literature which highlights the role of flexibility for firms (e.g., D'Acunto et al., 2018).

Second, the paper contributes to a new and emerging line of research on weather, climate risk and finance. For instance, in their early works, Hirshleifer and Shumway (2003) find a positive relation between sunshine and market returns. More recently, Krueger, Sautner, and Starks (2018) explore how climate change affects institutional investors' risk perception. Painter (2019) examines the impact of climate change

\footnotetext{
${ }^{4}$ Many firms in the food production industry need to adjust their production process to changing climatic conditions (https://www.theguardian.com/environment/2012/sep/19/climate-change-affect-food-production).

${ }^{5}$ Extreme weather could trigger a beer shortage because breweries could face shortages in their supply of barley (https://www.nature.com/articles/d41586-018-07015-7).

${ }^{6}$ Sales of beer or bottled water is strongly linked to weather conditions during the summer months in many countries (https://www.thelocal.no/20180719/norwegians-set-records-for-beer-consumption-during-hot-summer).

7 The tourism industry needs to adjust its "assets" because consumers' demand shifts to different regions (http://www.ktoo.org/2014/08/04/report-alaska-tourists-may-shift-new-areas-climate-change).

${ }_{8}$ Chinese steel producers have to cope with tougher environmental regulations to reduce pollution levels (http://www.reuters.com/article/china-steel-environment-idUSL4N0VE3R820150204).
} 
on the underwriting fees and initial yields of municipal bond issuance. Murfin and Spiegel (2019) studies the real estate price implications of the rise of sea levels. Our paper, to our best knowledge, is the first paper that explores how climate change and extreme weather conditions affect corporate investments.

Third, this paper also contributes to a long line of research about the economics of energy utilities. Frésard, Rose and Wolfram (2007), for instance, analyze how deregulation affects the efficiency of energy utilities. Becher, Mulherin, and Walkling (2012) investigate corporate mergers in the energy utilities industry, Perez-Gonzalez and Yun (2013) use energy utilities to measure the value of risk management with derivatives, and Rettl, Stomper, and Zechner (2016) evaluate the importance of competitor inflexibility in this industry. Reinartz and Schmid (2016) analyze the impact of production flexibility on the financial leverage in the electricity-generating industry, and Lin, Schmid, and Weisbach (2019) investigate how price risk due to electricity price volatility affects firms' cash holdings.

\section{Data description}

\subsection{Sample of energy utilities}

To construct a global sample of energy utilities, we start by combining lists of active and inactive public utility companies from Thomson Reuters. The sample covers the years 2000 to 2016, which is the period for which we can obtain the necessary annual data on firms' production assets. After cleaning the sample and filtering those firms which operate in regions with wholesale markets for electricity, ${ }^{9}$ we end up with 273 energy utilities.

Figure 1 shows the example of Vattenfall AB, a Swedish power company which had electricity generation capacity in Sweden, Denmark, Netherlands, Germany, the U.K. and Finland in 2014. For the construction of our dataset, we consider all electricity market regions in which a firm owns capacity as long

\footnotetext{
${ }^{9}$ First, we eliminate all firms without a primary security classified as equity. Second, we wish to consider only companies that focus on the generation of electricity. To ensure that other companies are not included, we rely on firms' SIC and ICB codes, their business description obtained from Capital IQ, and additionally conduct manual research on their business lines. Finally, we eliminate all firms that do not have any operations in regions with wholesale markets for electricity, and we exclude the Russian electricity market because weather-based measured are problematic for a market that spans multiple climatic zones.
} 
as the regional capacity accounts for at least one percent of the total production capacity and the fraction of renewable production capacity in that region is less than 50 percent. On average, every firm is active in about three different electricity markets (median: two markets). Overall, our sample firms are active in 43 electricity market regions from 32 countries, they operate 37,965 unique power plants, and plan to construct 4,425 new plants during our sample period.

\subsection{Measuring power plant investments}

Data on individual power plants is obtained from the annual versions of the Platts World Electric Power Plant database, which provides information on power plants around the globe. It includes information on single power plant units, including their production technologies, capacities, geographic locations, start dates of commercial operation, and their owners/operators. We obtain the annual version of this database for all years between 2000 and 2016 and manually match each power plant unit to the energy utilities sample. ${ }^{10}$ About one-third of the worldwide production capacity for electricity matches to our sample firms; the remainder are plants owned by large utilities that are not publicly listed or plants in nonderegulated regions without wholesale markets for electricity and are excluded from our sample for this reason.

Most important for our purposes, this database does not cover only completed power plants, but also contains information on planned plant construction projects. ${ }^{11}$ These data on existing power plants as well as planned power plant projects allow us to construct our investment variables. The variable "FLEXIBLE INVESTMENT" is defined as planned construction projects of flexible power plants (in megawatt, MW) of firm $i$ in region $j$ and year $t$, scaled by the capacity of existing power plants (in MW) of

\footnotetext{
${ }^{10} \mathrm{We}$ use the yearly version of the database because historical owner/operator information is not included.

${ }^{11}$ These are plants with the status code PLN, which means planned (still in planning or design). Platts states that "the decision to include new power projects in the WEPP Data Base is [...] made on a case-by-case basis. Key determinants in approximate order of importance are: 1) order placement for generating equipment or engineering, procurement, and construction (EPC) services, 2) the status of licensing or permitting activities, 3) funding, and 4) the availability of fuel or transmission access. Projects may also be included even if such data are lacking if there are generalized national or regional policies that are driving power plant development." (Platts Data Base Description and Research Methodology, p.19).
} 
the same firm $i$ in the same region $j$ and year $t$. The variable is set to one if the planned capacity exceeds the existing capacity. We classify power plants using gas, oil, or pump storage as production technology as flexible. The variables "INFLEXIBLE INVESTMENT", "RENEWABLE INVESTMENT", and "TOTAL INVESTMENT" are constructed in the same way, but we consider planned inflexible plants (coal and nuclear), renewable plants (wind and solar), or all planned plants.

For robustness, we also use alternative variables to measure flexible investment. First, we apply a dummy variable that equals one if firm $i$ has any planned flexible power plant projects in region $j$ and year $t$. Second, we use the unscaled logarithm of the total capacity of all flexible planned power plant projects of firm $i$ in region $j$ and year $t$. Third, we consider the number of planned power plants, rather than their capacity, scaled by the number of existing plants. Fourth, we use the logarithm of the number of planned flexible plants.

Table 1 provides an overview on the planned power plant projects, separately for flexible, inflexible, and renewable plants as well as the single technologies therein. There are 1,605 projects to construct flexible power plants, which account for a total of $401 \mathrm{GW}$. The average capacity of planned flexible plants is 216 MW (median: 183 MW). Most planned flexible plants are gas and gas combinedcycle plants. For inflexible plants, there are 612 projects with a capacity of $433 \mathrm{GW}$. The average planned inflexible plant has a capacity of about $810 \mathrm{MW}$ (median: $832 \mathrm{MW}$ ), about four times the average capacity of planned flexible plants. For renewables, we identify 1,079 projects, mostly in wind plants. Their combined capacity is $100 \mathrm{GW}$, and the average size of planned renewable plants is $74 \mathrm{MW}$ (median: 25 MW). The "others" group, which includes for example hydro, biogas, biomass, geothermal, or waste plants, is not explicitly considered when we distinguish the power plant types, but these plants are included in our analysis focusing on total investments. In total, there are 4,425 unique investment projects in our sample, which have a combined capacity of 1,046 GW. This amount is similar to today's installed electricity generation capacity of the U.S., which is about 1,100 GW according to the U.S. Energy Information Administration (EIA). 


\subsection{Measuring extreme weather}

Our weather data come from the Global Historical Climatology Network (GHCN). We use the daily average temperatures (GHCN-DAILY) to construct our measures of extreme weather. Based on approximately 200 million individual temperature observations at the weather station level, we start by calculating the average temperature in degrees Celsius in each market region and year from 1951 to $2016 .{ }^{12}$ The variable "EXTREME WEATHER" is then calculated as the fraction of days with an extreme temperature in a particular year and market. A day is classified as extreme if its temperature would belong to the one percent hottest or coolest days during the base period 1951 to $1980 .{ }^{13}$ In the absence of climatic changes, we would expect to classify one percent of days as extremely hot and one percent of day as extremely cold during our sample period 2000 to 2016, which leads to an expected value for this variable of two percent. For robustness tests, we alternatively classify the hottest and coldest 0.5 percent or five percent as "extreme" days, only consider hot days, or use weekly instead of daily temperatures.

The average values of the extreme weather variable across all markets over time are presented in Figure 2. This figure documents that the fraction of extreme days shows an increasing trend since the end of the base period in 1980, as both the linear and the quadratic fits are upward sloping. During our sample period, 3.4 percent of all days are classified as extreme weather days, which is substantially more than the two percent which we would expect if temperatures stayed the same as during the base period. If we weight the temperature observations by firms, the fraction of extreme days is 2.8 percent (see Table 2). These observations clearly indicate that extreme weather became more common during the last decades, a development that is likely related to climate change.

\footnotetext{
${ }^{12}$ Temperatures are calculated as the average across all weather stations in an electricity market region. This approach is potentially problematic for very large market regions like Russia, which spans multiple climatic zones. As explained before, we therefore exclude Russia from the sample.

${ }^{13}$ Hansen et al. 2012 explain they "choose 1951-1980 as the base period for most of our illustrations, for several reasons. First, it was a time of relatively stable global temperature, prior to rapid global warming in recent decades. Second, it is recent enough for older people, especially the "baby boom" generation, to remember. Third, global temperature in 1951-1980 was within the Holocene range, and thus it is a climate that the natural world and civilization are adapted to. We require at least 20 years of non-missing data on the average temperature during this base period.
} 


\subsection{Control variables}

Our source for financial variables is Worldscope. The financial control variables which we use are size (measured as the logarithm of total assets in \$US), profitability (EBITDA scaled by total assets), Tobin's Q (market capitalization of equity plus total liabilities scaled by the sum of the book value of equity plus total liabilities), leverage (total debt scaled by the sum of total debt and book value of equity), and cash holdings (cash and short-term equivalents scaled by total assets). We also control for the two country-level variables GDP per capita and inflation rate, which are based on Worldbank data, to account for the fact that electricity consumption and economic development can be correlated (Da, Huang, and Yun, 2017). All variables are winsorized at the $1 \%$ and $99 \%$ levels; their detailed descriptions can be found in Appendix A.

\subsection{Descriptive statistics}

Table 2 presents descriptive statistics for our sample firms, averaged for the whole sample period. On average, the planned investments in flexible power plants account for 7.9 percent of the existing capacity of energy utilities. The respective numbers for investments in inflexible and renewable plant projects are 4.9 percent and 2.3 percent. If we consider all power plant projects, investments account for 17.8 percent of the existing capacity. On average, 2.8 percent of all days are classified as days with extreme temperatures. The firm-level variables indicate that the energy utilities in our sample are comparatively large, with average total assets of about 26 billion USD.

\section{Estimating the impact of extreme weather conditions on utilities' investments}

\section{$\underline{\text { 3.1. Empirical specification }}$}

The dataset which we use for firm-level regressions is organized as a firm-region-year panel. We estimate an equation predicting investment for a particular firm in each region in which it operates. We first present a specification with just year effects. This specification has the advantage of utilizing both time series and cross-sectional variation in extreme weather. However, it does not control for firm or region level omitted variables. We next estimate a specification that contains year, region, firm, and firm times 
region fixed effects. This specification only exploits variations in the frequency of extremely hot or cold days within a particular market region in which a firm operates. Finally, we estimate a specification that includes firm times year fixed effects. This specification exploits the fact that many firms in our sample, as is illustrated for Vattenfall in Figure 1, operate in more than one region. All standard errors for firm-level regressions are clustered by country and firm. For analyses which do not require firm data, we use data organized as a region-year panel and cluster standard errors by country.

\subsection{Estimates of the impact of extreme weather on investments}

We present estimates of these specifications in Table 3. We start with investments in flexible power plants (gas, oil, and pump storage) in Panel A. Theoretically, extreme weather should affect investments in these types of power plants since they can better adjust production levels when electricity demand and price volatility increase because of more extreme weather conditions. All columns include year-fixed effects; Columns 2 and 3 include firm, region, and firm times region fixed effects, and Column 4 additionally includes year x firm-fixed effects. In each specification, the estimated coefficient for extreme weather is positive and statistically significantly different from zero. This positive coefficient indicates that firms' investments in flexible power plants are higher in regions in which temperature are more extreme.

The magnitude of the coefficient for extreme weather is 0.87 when both time-series and crosssectional variation are used. When we only exploit variation of extreme weather over time, the estimated coefficient is between 0.51 and 0.55 , depending on whether controls and firm times year fixed effects are included or not. These estimates imply that a one-standard deviation change of the frequency of extremely hot days leads to a 1.3 to 2.3 percentage point increase in flexible investment (which is defined as the capacity of planned flexible power plants relative to existing plants). Because the average flexible investment is 7.9 percent, these numbers translate into a relative increase of 16 to 29 percent. The estimates also imply that flexible investment increases by 0.5 to 0.9 percentage points if one percent more days exhibit extreme weather than in the base period. Thus, this effect is not only statistically significant, but also large 
enough to be economically relevant. The effect of the control variables is in line with expectations: large firms and those with higher market to book ratios invest more on average.

A graphical illustration of this effect can be found in Figure 3 in which we plot the average flexible investment for extreme weather deciles. In line with our regression results, there clearly a positive relation between both variables. Panel B presents the estimates for inflexible plants (nuclear and coal), renewable plants (wind and solar), and all power plants. The coefficient estimates for both inflexible and renewable plants are negative, but they are not significantly different from zero. For all power plants, we find positive coefficient estimates that are statistically significant. These results suggest that more extreme weather conditions lead to an overall increase in power plant investments that is made up primarily of those with flexible generation.

\subsection{Robustness tests: market power, input prices, and market-specific effects}

We evaluate several potential concerns for the validity of our results in Table 4. First, we focus on the market power of firms. Firms with a (very) high market power could conceivably influence electricity price characteristics through their bidding behavior. If the effect of market power occurs more often when there is more extreme weather, then our results could reflect this market power. However, as we show in Panel A, our results also hold if we exclude firms that account for more than 20 percent, 10 percent, or one percent of the production capacity in a particular market. The finding that the interaction term between extreme weather and market share is not statistically significant also mitigates the concern that our results are driven by firms' market power.

In Panel B, we analyze explicitly control for the gas price and the spark spread (i.e., the difference between the wholesale price of electricity and the cost of natural gas, see Appendix A for a detailed description of both variables). If extreme weather had a direct on gas prices or spark spreads, our previous results might not capture a direct effect of extreme weather on investment. However, the estimates in Panel

B show the extreme weather has a strong positive impact on flexible investments even after controlling for gas prices or spark spreads, or interacting both centered variables with extreme weather. Not surprisingly, 
spark spreads themselves are also linked to flexible investments, with higher spark spreads leading to more flexible plants being constructed because of their higher profitability.

We also subsequently exclude all single markets to make sure that we document a general effect which is not driven by one particular region. Figure 4 shows the coefficient estimates for our base specification in Table 3, Panel A, Column 2 when we exclude single markets. The results indicate that we document a general effect which is not driven by any particular market.

\subsection{Robustness tests: alternative specifications}

Appendix B contains estimates using alternative specifications. The first, which is presented in Panel A, focuses on the way in which of extreme temperatures. In the analysis presented in Table 3 , we classify a day as extreme if it would belong to the hottest or coldest one percent of days in the same region during the base time period (1951-1980). We present specifications redefining our measure of extreme weather classifying a day as extreme if it belongs to the hottest or coldest 0.5 percent or 5 percent of days, or we only consider the hottest one percent of days. The estimates presented in Columns 1 to 3 show that these alternative measures of extreme weather also have a positive impact on investments in flexible plants. In Column 4, we use weekly instead of daily temperatures and find similar results.

Panel B contains estimates using alternative definitions for flexible investment, which scales the total capacity of planned flexible power plants by the capacity of the existing generation assets in the same region. In Column 1 we instead use a dummy variable that equals one if a firm has any investments in flexible plants and zero otherwise. In Column 2, we use the non-scaled natural logarithm of one plus the total capacity of planned flexible plants. Columns 3 and 4 focus on the number of plants instead of their capacity. In these specifications, we use the number of planned flexible plant projects, scaled by the number of existing plants, and the natural logarithm of one plus flexible plant projects. The estimates in each specification suggest that extreme weather leads to more investments in flexible power plants.

The third series of robustness tests in Panel $\mathrm{C}$ includes alternative fixed effects. We include year and firm fixed effects in Column 1, year and region fixed effects in Column 2, and year plus region plus 
firm fixed effects in Column 3. In Column 4, we add year times continent fixed effects to our main specification to allow for continent-specific time trends. All these specifications indicate that more extreme weather conditions lead to more investments in flexible power plants. Instead of clustering standard errors by firm and region, Panel D shows the outcome if we cluster standard errors by firms (Column 1), regions (Column 2), regions and years (Column 3), or regions plus years plus firms (Column 4). The results are similar to those of our main specification.

Panel E adds additional controls for regional characteristics besides those already included in Table 3. Although extreme weather is likely to be exogenous to country-level factors, we nevertheless add controls for capital market development in Column 1. These are stock market capitalization and domestic credit to the private sector, both scaled by a country's GDP. In Column 2, we add the electricity market characteristics total production capacity, average capacity share of flexible power plants, and years since the incorporation the electricity market. Columns 3 controls for firm-specific operations in a market by adding its production capacity in this market and the share of this market for its total capacity. Finally, Column 4 includes all these additional control variables at the same time. The estimates using each of these specifications are similar to the ones reported in Table 3.

\section{The Channel through Which Extreme Weather Affects Investments}

We have documented that changes in extreme temperatures lead firms to increase their construction of new power plants, with the increase coming from plants that rely on relatively flexible production technologies. A possible reason why firms invest in flexible generation is that more frequent extreme weather conditions increase the volatility of electricity demand and prices, which would lead firms to favor production techniques for which quantities can be easily adjusted to changing market conditions. To evaluate the extent to which increased electricity price volatility is the reason why more extreme temperatures lead to increased construction of flexible power plants, we examine the underlying hypothesis of this argument: that more extreme weather conditions do in fact increase the volatility of electricity demand and prices. 


\subsection{Other weather characteristics, electricity demand, and electricity prices}

We start by examining the way in which other weather characteristics change when the weather becomes more extreme. Our estimates in Panel A of Table 5 are based on region-year level regressions and indicate that the numbers of both cooling and heating degree days increase. Cooling degree days in Column 1 measure the cooling demand as the difference between the average outside temperature and a base temperature of 18.3 degrees Celsius. Heating degree days in Column 2 approximate the heating demand by how much the outside temperature is below the base temperature of 15.5 degrees Celsius. The increase of cooling and heating degree days suggests that the demand for heating and cooling rises when the weather becomes more extreme. At the same time, outside temperature become more volatility, as indicated by the higher standard deviation of temperatures and their logarithm in Columns 3 and 4.

These changing weather characteristics likely affect electricity demand. The demand tests in Panel B focus on IEA data for U.S. regions because monthly demand data is not available elsewhere. Column 1 shows that residential consumption increases, which is in line with the idea that (residential) electricity demand is closely linked to temperatures due to heating and/or cooling needs (Perez-Gonzalez and Yun, 2013). In Column 2, we analyze total electricity consumption, which consists of residential, commercial, industrial, and transportation consumption. We find that the total consumption has a lower coefficient estimate which is not significantly different from zero, indicating that extreme weather has limited effects on the overall electricity demand. However, when we turn to volatility of the overall electricity demand, ${ }^{14}$ we find clear evidence that more extreme weather leads to a more volatile demand, no matter whether we use the volatility itself or its logarithm (Columns 3 and 4). This finding indicates that more extreme weather affects electricity demand mainly by increasing the volatility of the demand, not necessarily its level.

These demand-side changes affect wholesale prices for electricity. To measure the wholesale electricity price level and volatility, we collect data on electricity prices from different sources, e.g., directly from the websites of the exchanges (see Lin, Schmid, and Weisbach, 2019, for more details). We then

\footnotetext{
${ }^{14}$ Demand volatility is approximated as the standard deviation of monthly electricity generation within a year, normalized by the market's average generation.
} 
calculate electricity price volatility as the standard deviation of hourly electricity prices, normalized by the market average. Electricity prices are measured in US\$ per megawatt hour (MWh) and local electricity prices are converted to US\$ using daily exchange rates. We use the logarithm of the price and its volatility to restrict the impact of extreme values. For the price level in Columns 1 and 2, we find positive point estimates, but they are marginally insignificant no matter whether we control for GDP per capita and inflation or not. This result is in line with the finding that total consumption does not increase significantly. Also consistent with the higher electricity demand volatility, we find that electricity price volatility increases substantially if temperatures become more extreme. The point estimates suggest that a onestandard deviation increase of the frequency of extremely hot or cold days lead to an electricity price volatility increase of about 15 to 20 percent, depending on whether we include regional control variables. Consistent with our electricity demand result, these tests suggest that extreme weather has a strong impact on the volatility of electricity prices, but not necessarily their level.

In Panel D of Table 5, we use electricity prices and their volatility directly as an independent variable in models explaining flexible investments. These tests, which are conducted at the firm-regionyear level as our main analyses, show that there is no statistically significant impact of the electricity price level on flexible investments (Column 1). In Column 2, we find that higher electricity price volatility increases planned investments in flexible plants. These results are similar if we include both the electricity price level and the volatility in the regression with or without additional control variables (Columns 3 and 4). We conclude that higher electricity price volatility due to more extreme weather conditions is a likely channel for firms' increases in planned investments in flexible generation.

\section{$\underline{4.2 . ~ A l t e r n a t i v e ~ m e c h a n i s m ~ t e s t s ~}$}

An alternative explanation for our findings could be that extreme weather leads to a higher public or political pressure for environmental-friendly electricity production. This pressure could have two effects: first, firms would use more solar and wind generation in regions in which the weather is more extreme. Because wind and solar are intermittent generation technologies, flexible plants would be needed to take 
care of generation if they cannot produce electricity. Following this logic, more extreme weather could lead to more investments in flexible generation because a higher penetration of renewables makes flexible plants more valuable. However, when we analyze this potential mechanism in Appendix C, Panel A, we find no empirical support for its validity. Neither is there any correlation between extreme weather and renewable penetration (which is in line with our previous result that extreme weather does not affect investments in renewables), nor does renewable penetration directly affect flexible investment.

The second potential consequence of this higher awareness for environmental issues could be that firms could prefer flexible gas-fired plants over inflexible coal-fired plants not because of their differences in flexibility, but because gas plants are less detrimental to the environment than coal plants. To evaluate whether this potential mechanism explains our findings, we use the Environmental Policy Stringency index (EPSI).$^{15}$ If extreme weather affects flexible investments via this environmental awareness channel, we would expect to find that more extreme weather leads to a stricter environmental policy and higher values of the EPSI. However, we find no evidence for such relation in Columns 1 and 2 of Panel B, Appendix C. When we use the EPSI directly in regressions explain flexible investments, we find no evidence for any relation between those two as well (Columns 3 and 4). We conclude that higher environmental awareness due to more extreme weather is unlikely to cause our main results.

\section{Extreme weather predictability, operating flexibility, and weather forecasting}

\subsection{What do current realizations of extreme weather reveal about the future?}

To this point we have argued that firms increase investments in flexible generation when the weather becomes more extreme to increase their future operating flexibility. The logic of this argument depends on more extreme weather conditions today being associated with more extreme weather conditions in the future when the newly constructed plants go online. To evaluate the predictive power of current

\footnotetext{
${ }^{15}$ This index, which is developed by the OECD, "is a country-specific and internationally-comparable measure of the stringency of environmental policy. Stringency is defined as the degree to which environmental policies put an explicit or implicit price on polluting or environmentally harmful behaviour" (https://doi.org/10.1787/2bc0bb80-en).
} 
extreme weather realizations for the future, we use a forecasting model and investigate how the forecast error changes when we include or exclude the latest extreme weather realization in the calibration.

For the model calibration, we use ten years of past extreme weather data to calibrate a marketspecific linear trend function. We then forecast the average extreme weather for the next three, five, and ten years. Table 6 reports the average absolute forecast error across all markets and years. In the first column, we include the most recent extreme weather realization in the calibration period ( $t-9$ to $t=0)$. In the second column, we exclude the most recent extreme weather realization and use the ten-year period from t-10 to t-1 to calibrate the model. The third column shows the relative difference in the mean absolute forecast error when including or excluding the most recent realization.

The results show that including the most recent extreme weather realization for the calibration of the model reduces the forecast error by about five to ten percent relative to a calibration which excludes the most recent realization. This finding indicates that adjusting investment plans based on realization of extreme weather is meaningful because these realizations are useful for updating predictions about future weather conditions.

\subsection{The role of operating flexibility}

Our hypothesis is that energy firms invest in flexible generation assets to increase their operating flexibility and adjust to more volatility electricity prices. An important issue is the extent to which utilities' operating flexibility does in fact change because of these investments. To address this issue, we follow two approaches. First, we calculate the difference between a firm's current operating flexibility and the flexibility it would have once all planned power plants have been completed, where we define operating flexibility as the ratio of flexible production capacity to the sum of flexible and inflexible capacity. The second approach considers realized changes in operating flexibility, calculated as the relative change in operating flexibility between now and four years in the future. These comparisons are presented in Table 6, Panel A. This panel documents that more extreme weather conditions increase both the planned and realized change in operating flexibility. 
An additional prediction is that a firm's existing operating flexibility should affect its likelihood to invest in flexible power plants. More volatile electricity prices coming from more extreme weather conditions should be especially problematic for firms with low levels of existing operating flexibility. Thus, we expect that investments in flexible generation should be larger for firms with existing flexibility. Panel B of Table 6 presents estimates of equations predicting investments in flexible power plants as a function of firms' existing flexibility. We define existing operating flexibility as a firm's flexible production capacity scaled by the sum of flexible and inflexible capacity. In the first two columns, we split the sample into observations with above and below median operating flexibility. Extreme weather conditions have a very strong positive impact on flexible investments for firms with low levels of operating flexibility in Column 1. Although extreme weather also has a positive effect on flexible investments in firms with higher levels of operating flexibility, the coefficient estimate in Column 2 is substantially smaller (0.37 vs 0.84$)$. Using an interaction term for the full sample of firms confirms this result. Both in specifications without or with (Columns 3 and 4) control variables, we find that extreme weather leads to more investments in flexible plants, but the interaction term between extreme weather and operating flexibility is negative. Assuming a firm with only flexible power plants, these estimates imply that extreme weather conditions would not trigger investments in flexible plants for such a firm with an operating flexibility value of one (coefficient estimates of 1.39 versus -1.40 in Column 4). These estimates suggest that investments in flexible assets are concentrated in firms with lower levels of existing operating flexibility.

\section{$\underline{\text { 5.3. Weather forecasting and the impact of extreme weather on flexible investments }}$}

One factor that could potentially affect the impact of extreme weather on flexible investment is the weather forecasting accuracy. If market operators and firms have precise forecasts about changes of temperatures and demand, they can prepare and plan long or medium-term electricity generation adjustments. On the other hand, highly flexible plants are needed if temperature and demand changes occur unexpectedly, especially if extreme temperatures are common. As a consequence, we expect that extreme 
weather has a stronger positive impact on flexible investments especially in regions in which weather forecasting is less accurate.

We obtain detailed temperature forecast data from multiple forecast providers from ForecastWatch. ${ }^{16}$ We focus on the three-day temperature forecast, which is available for the U.S. from 2005, Canada from 2007, and other countries from 2012. The forecast error for a particular day is calculated as the absolute value of the three-day forecast average temperature forecast, averaged across all forecast providers, minus the actual average temperature on that day. We then calculate the average of all daily forecast errors in a given year and market region. Alternatively, we calculate forecast dispersion as the inter-quartile range of 3-day temperature forecasts across different forecast providers to measure for forecast uncertainty.

Table 8, Panel A, shows that extreme weather has a positive impact on flexible investments in regions and years in which the average 3-day temperature forecast error is above or below the median (Columns 1 and 2). However, the coefficient estimate is higher for the high forecast error subsample $(0.65$ vs. 0.34). When we interact the forecast error with extreme weather in Columns 3 and 4, we again find that extreme weather has a stronger impact on flexible investments if the forecast error is higher. The results for forecast dispersion, which are presented in Panel B, are similar to those for the forecast error and indicate that higher firms react stronger to weather uncertainty if temperature forecast uncertainty is high.

\section{Conclusion}

The changing climate is potentially one of the most consequential phenomena in human history. Much attention has been focused on the way changing weather patterns affects ocean levels, the likelihood and violence of storms, and agricultural productivity. Yet, there are many other potential effects of climate change that could impact many aspects of the economy. Firms in a number of different industries will have

\footnotetext{
${ }^{16}$ According to their website, they "collect weather forecast data from thousands of locations throughout the U.S. and around the world [...]. This information is added to an ever-growing and unparalleled historical database of more than 800 million weather forecasts gathered from a variety of resources" (www.forecastwatch.com/about-us/).
} 
to alter the way that they do business, sometimes in a substantial way. The ability to adjust their operations quickly to new situations and market conditions has potentially become more important. We study the effect of the frequency of extreme temperatures on one industry that is likely to be considerably affected by it, the electricity producing industry.

A major factor in the demand for electricity is the weather. Theoretically, more extreme temperatures can lead to large fluctuations in electricity demand and the wholesale price of electricity, which in turn affects the optimal production process for firms to use. Especially flexible power plants which can quickly adjust their production to changing market conditions can become more valuable in such a situation, and firms might increase their investments in those types of plants. Alternatively, climate change and extreme weather can increase uncertainty for energy firms, causing them to delay their investments.

In this paper, we consider a sample of 273 electricity producing firms operating in 43 electricity markets over the 2000-2016 period. These firms have 4,425 planned power plant projects, of which 1,605 are flexible gas, oil, or pump storage plants. We evaluate the extent to which changes in the regional frequency of extreme temperatures affected our sample firms' decisions to invest in new power plants. The estimates indicate that the quantity of new, flexible power plants that firms build increases in regions in which temperatures are becoming more extreme. These estimates imply that a one standard deviation increase in the frequency of days with extreme temperatures leads to a 15 to 25 percent relative increase in investments in flexible plants, suggesting that changes in weather have had a substantial impact on these firms' investment decisions. We show that the mechanism for this increase is that extreme weather leads to more volatile temperatures, which then leads to more volatile electricity demand and prices. Firms react to this higher volatility by investing in a way that improves their operating flexibility.

These results are consistent with the view that the effects of climate change have affected the investment decisions of electricity producing firms. Presumably, as the earth continues to warm and weather becomes even more extreme, firms will continue to favor flexible power plants for which output can be adjusted easily. Ironically, the type of plant most responsible for the $\mathrm{CO}_{2}$ emissions that cause climate change is the coal-fired plant. These plants are relatively inflexible, so have a relatively high cost of 
changing their output. Consequently, because of climate change, firms appear to be shifting away from the coal fired plants, not because of their $\mathrm{CO}_{2}$ emissions, but because of their inflexibility. Unfortunately, the weather induced shift has not been to renewable energy, although there has been an increase in renewables for other reasons.

While investments in power plants are an important topic, we hope our paper makes a larger point: changing weather conditions fundamentally changes the economics of many businesses. Our results suggest that it leads energy producing companies to increase investments to enhance their operating flexibility. In addition, changing weather conditions potentially lead firms to invest more in other industries as well. However, the impact of culminate change on the way firms in different industries invest is likely to vary substantially. Future research that characterizes the way in which climate change affects different industries is likely to be fruitful. 


\section{References}

Abel, A. B. (1983) "Optimal investment under uncertainty", American Economic Review, 73, 228-233.

Allianz (2013): The Weather Business - How Companies Can Protect Against Increasing Weather Volatility. Industry report.

Bar-Ilan, A. and Strange, W.C. (1996) "Investment lags," American Economic Review, 86, 610-623.

Becher, D. A., J. H. Mulherin, and R. A. Walkling (2012) "Sources of Gains in Corporate Mergers: Refined Tests from a Neglected Industry”, Journal of Financial and Quantitative Analysis 47, 57-89.

Billet, M. T., J. A. Garfinkel and Y. Jiang (2011) „The influence of governance on investment: Evidence from a hazard model," Journal of Financial Economics, 102, 643-670.

Bloom, N. (2009) “The impact of uncertainty shocks,” Econometrica, 77, 623-685.

Bolton, P., H. Chen, and N. Wang (2013) "Market timing, investment, and risk management," Journal of Financial Economics, 109, 40-62.

D'Acunto, F, R. Liu, C. Pflueger, and M. Weber (2018) "Flexible Prices and Leverage," Journal of Financial Economics, 129, 46-68.

Da, Z., D. Huang, and H. Yun (2017) “Industrial Electricity Usage and Stock Returns," Journal of Financial and Quantitative Analysis, 52, 37-69.

Dixit, A. K. (1980) “The role of investment in entry-deterrence,” Economic Journal, 90, 95-106.

Dixit, A. K. and Pindyck, R. S. (1994) "Investment under Uncertainty," Princeton University Press, Princeton

Fabrizio, K., N. Rose, and C. Wolfram (2007) "Do Markets Reduce Costs? Assessing the Impact of Regulatory Restructuring on US Electric Generation Efficiency," American Economic Review 97, 125077.

Gan, J. (2007a) "Collateral, debt capacity, and corporate investment: Evidence from a natural experiment", Journal of Financial Economics, 85, 709-734.

Gan, J. (2007b) "The Real Effects of Asset Market Bubbles: Loan- and Firm-Level Evidence of a Lending Channel," Review of Financial Studies, 20, 1941-1973.

Giroud, X. (2013) "Proximity and Investment: Evidence from Plant-Level Data," Quarterly Journal of Economics, 128, 861-915.

Giroud, X. and Mueller, H. (2019) 'Firms' Internal Networks and Local Economic Shocks," American Economic Review, 70, 1767-1804.

Gulen, H. and Ion, M. (2015) "Policy Uncertainty and Corporate Investment," Review of Financial Studies, 29, 523-564. 
Hansen, J., Sato, M., Glascoe, J., and Ruedy, R. (1998) "A common-sense climate index: Is climate changing noticeably?” Proceedings of the National Academy of Sciences 95 (8), 4113-4120.

Hansen, J., Sato, M., and Ruedy, R. (2012) "Perception of climate change," Proceedings of the National Academy of Sciences 109 (37), 241-2423.

Harford, J. and V.B. Uysal (2014) "Bond market access and investment," Journal of Financial Economics, $112,147-163$.

Hirshleifer, D. and Shumway, T. (2003) “Good Day Sunshine: Stock Returns and the Weather”, Journal of Finance, 58, 1009-1032.

Julio, B. and Yook, Y. (2012) "Political Uncertainty and Corporate Investment Cycles," Journal of Finance, 67, 45-83.

Krueger, P., Sautner, Z., and Starks, L. "The Importance of Climate Risk for Institutional Investors," Review of Financial Studies, forthcoming.

Lin, C., Schmid, T., and Weisbach, M. S. (2019) "Price Risk, Production Flexibility, and Liquidity Management: Evidence from Electricity Generating Firms," NBER Working Paper No. 23434.

McDonald, R. and Siegel, D. (1986) "The value of waiting to invest," Quarterly Journal of Economics, $101,707-727$.

Murfin, J. and Spiegel, M. (2019) "Is the risk of sea level rise capitalized in residential real estate?," Review of Financial Studies, forthcoming.

Painter, M. (2019) “An inconvenient cost: The effects of climate change on municipal bonds," Journal of Financial Economics, forthcoming.

Pérez-González, F. and Hayong, Y. (2013) "Risk Management and Firm Value: Evidence from Weather Derivatives," Journal of Finance, 68, 2143-2176.

Reinartz, S. and Schmid, T. (2016) "Production Flexibility, Product Markets, and Capital Structure Decisions," Review of Financial Studies, 29, 1501-1548.

Rettl, D. A., Stomper, A.m and Zechner, J. (2016) "The Stability of Dividends and Wages: Effects of Competitor Inflexibility," Working Paper. 


\section{Vattenfall's electricity generation in Europe 2014, TWh}

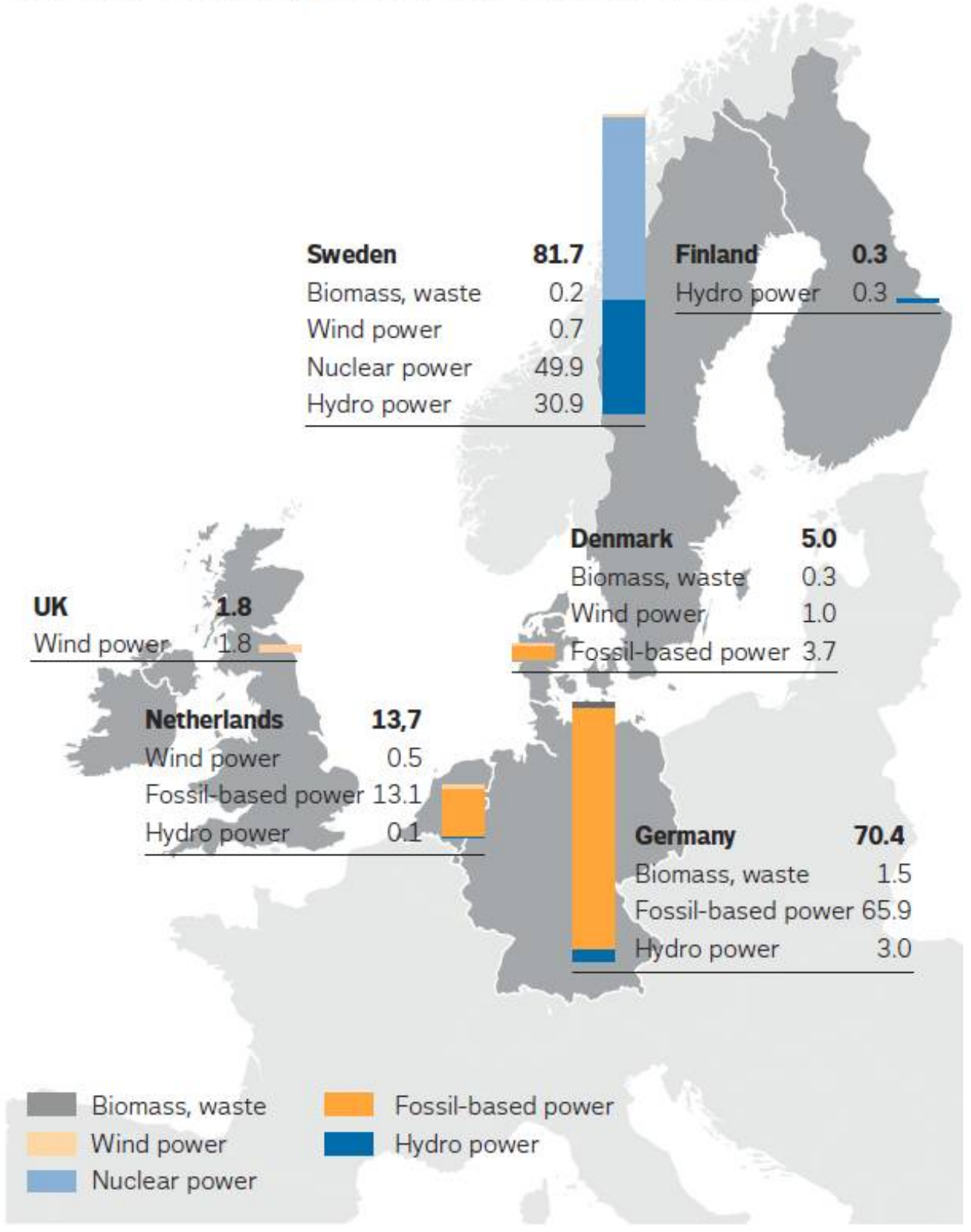

Figure 1: To illustrate our data structure, this figure shows the main countries in which Vattenfall AB owns production capacity (Source: Vattenfall annual report 2014). In our dataset, we observe Vattenfall's existing production capacity as well as planned new power plants individually for each electricity market (and year). 


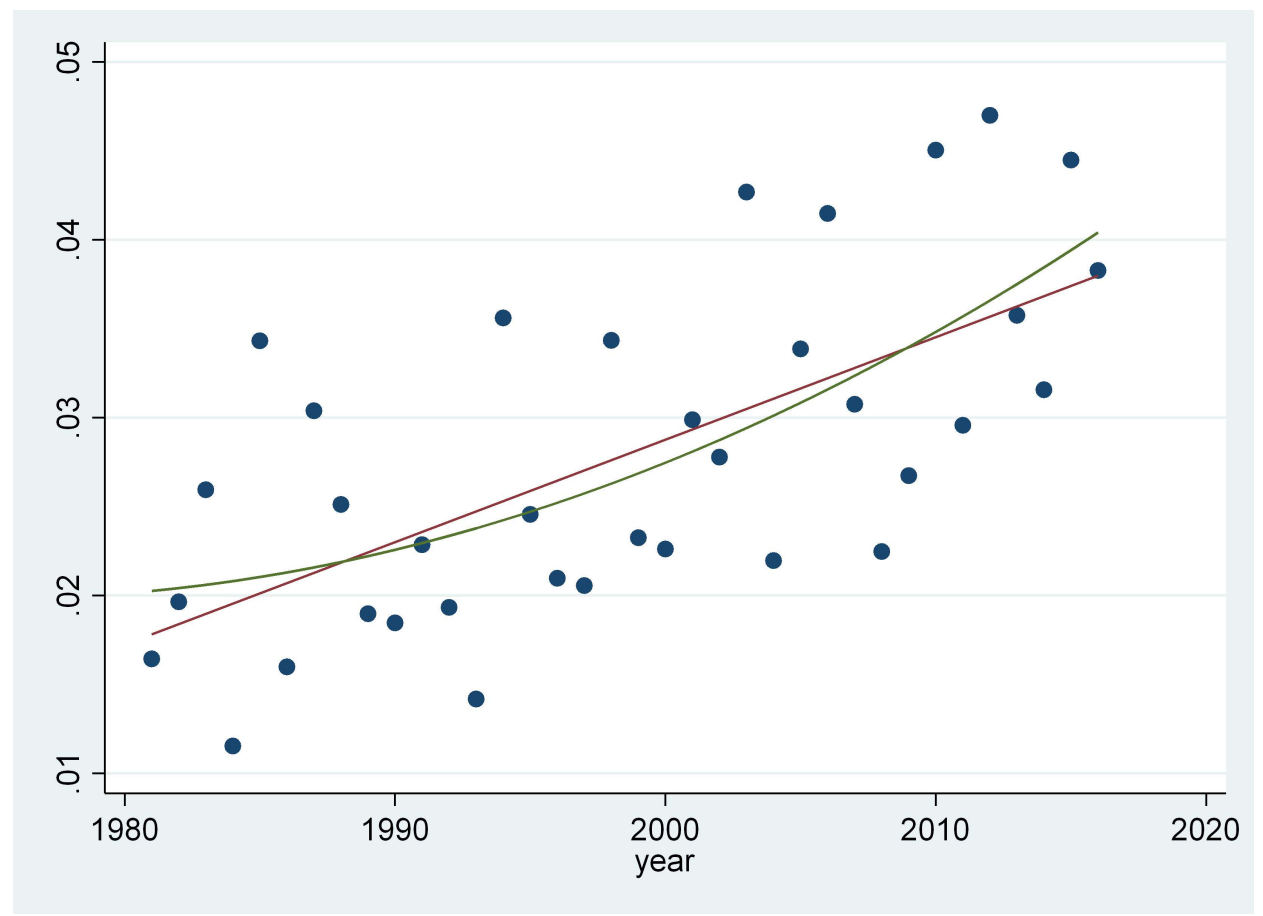

Figure 2: Average fraction of days with extreme temperature over time. A day is classified as extreme if its temperature would belong to the $1 \%$ hottest or coolest days during the base period 1951 to 1980 . A value of $2 \%$ indicates that extremely hot or cold days are equally common than during the base period. Linear and quadratic fits are shown in red and green, respectively.

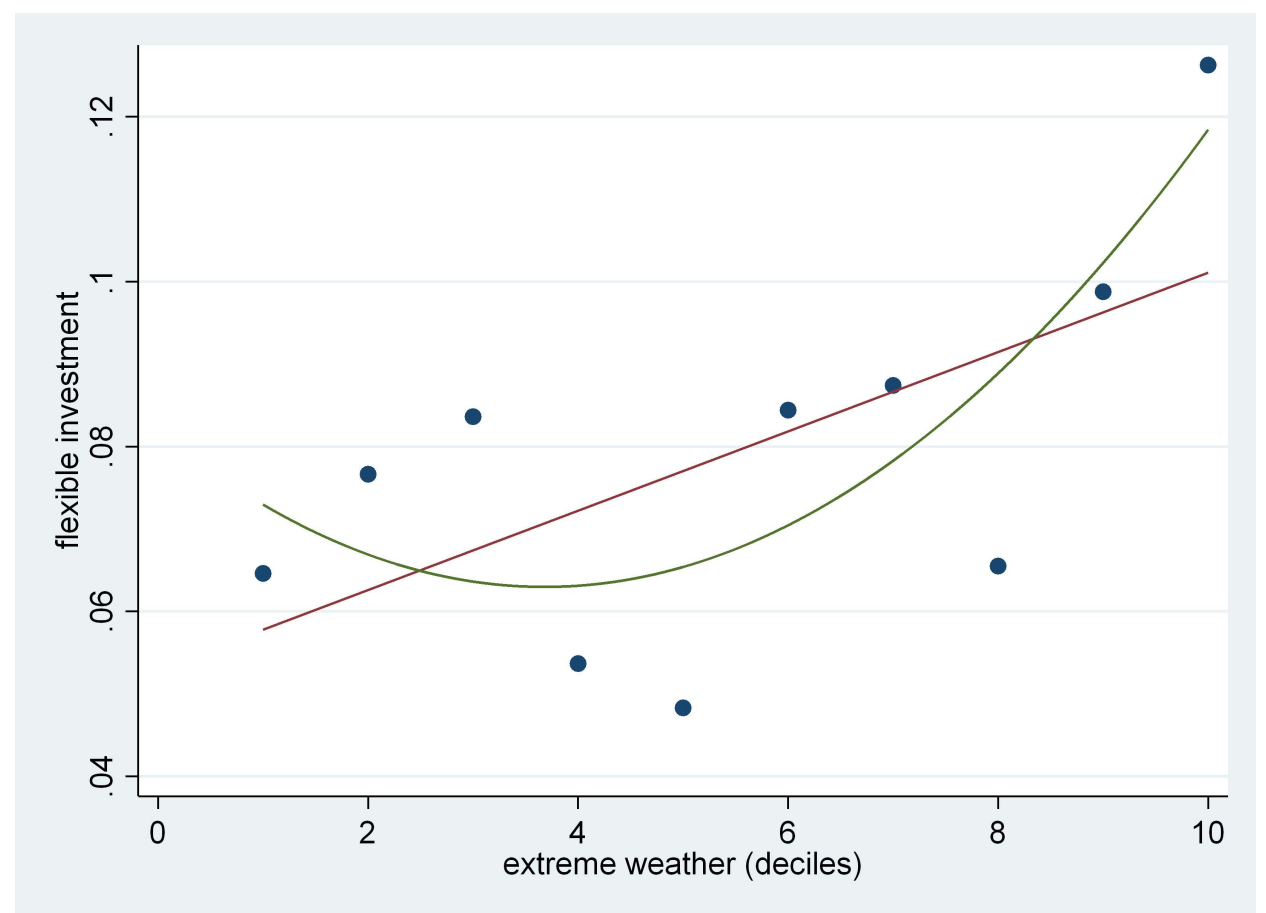

Figure 3: Flexible investments for extreme weather deciles. Linear and quadratic fits are shown in red and green, respectively. 


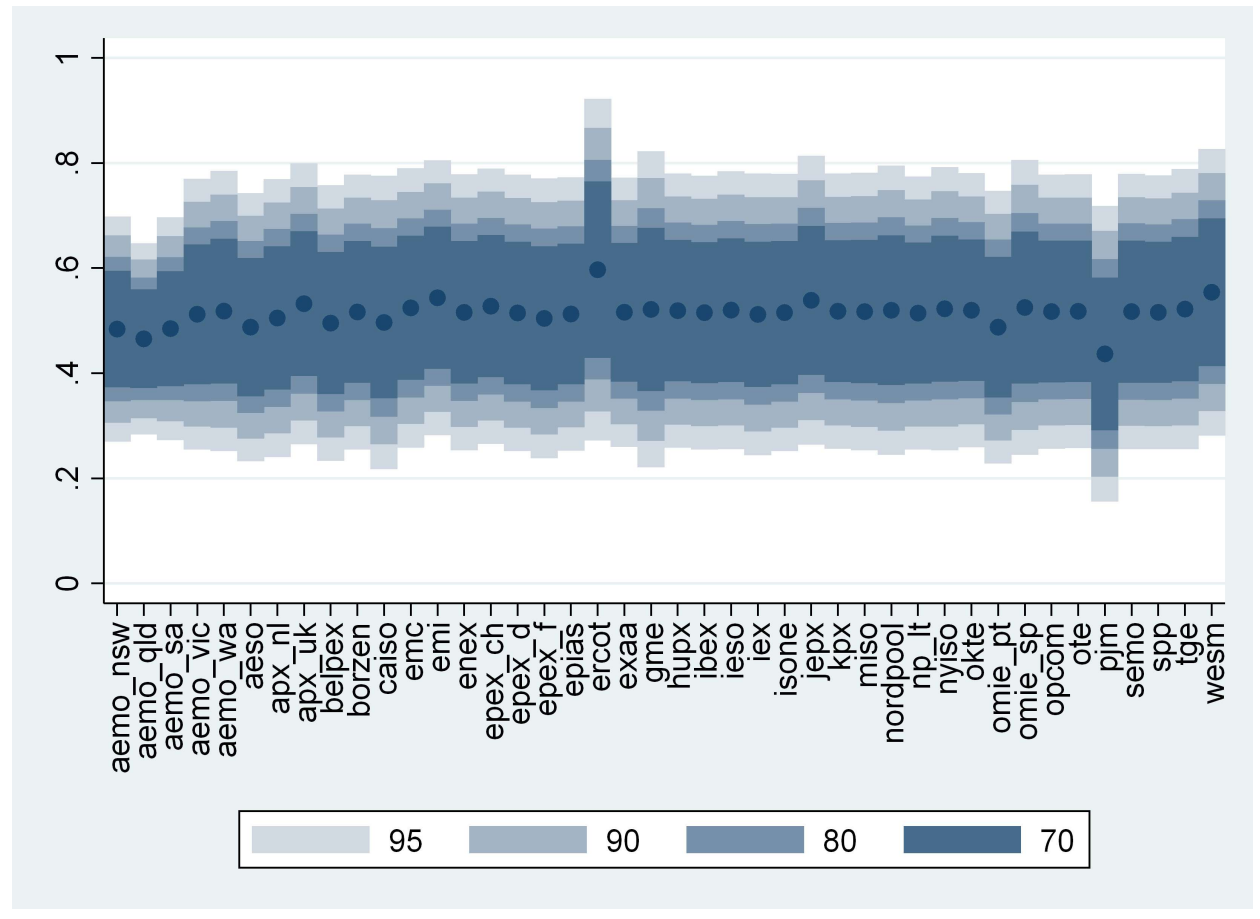

Figure 4: Coefficient estimates for our base model in Column 2 of Table 3 when we subsequently exclude single markets. 
Table 1: Descriptive statistics: planned power plant projects

\begin{tabular}{lcccc}
\hline & \multicolumn{2}{c}{ total } & \multicolumn{2}{c}{ capacity (MW) } \\
technology & number & GW & average & median \\
\hline Flexible & 1,605 & 401 & 216 & 183 \\
Oil & 121 & 6 & 50 & 18 \\
Gas & 715 & 98 & 138 & 65 \\
Gas comb. cycle & 675 & 271 & 402 & 400 \\
Pump storage & 94 & 26 & 274 & 250 \\
Inflexible & 612 & 433 & 810 & 832 \\
Coal & 484 & 301 & 623 & 660 \\
Lignite & 44 & 22 & 506 & 455 \\
Nuclear & 84 & 109 & 1,300 & 1,380 \\
Renewable & 1,079 & 100 & 74 & 25 \\
Solar & 237 & 9 & 39 & 10 \\
Wind & 842 & 91 & 108 & 40 \\
Other & 1,129 & 112 & 143 & 143 \\
\hline Total & 4,425 & 1,046 & 236 & 100 \\
\hline
\end{tabular}

This table presents descriptive statistics for the planned investment projects of the sample firms. Reported are the total number of power plant projects, the total capacity of planned plants in gigawatt $(\mathrm{GW})$, and the average and median capacity of planned plants in megawatt (MW). 
Table 2: Descriptive statistics: firm-level

\begin{tabular}{lcccc}
\hline Variable & Obs & Mean & p50 & SD \\
\hline Flexible investment & 4978 & 0.079 & 0.000 & 0.207 \\
Inflexible investment & 4978 & 0.049 & 0.000 & 0.184 \\
Renewable investment & 4978 & 0.023 & 0.000 & 0.106 \\
Total investment & 4978 & 0.178 & 0.000 & 0.309 \\
Extreme weather & 4978 & 0.028 & 0.019 & 0.026 \\
Price volatility & 4361 & 0.726 & 0.406 & 1.070 \\
Log(price volatility) & 4361 & -0.731 & -0.902 & 0.764 \\
Assets (USD bn) & 3836 & 25.810 & 13.383 & 30.167 \\
Log(assets) & 3836 & 15.999 & 16.410 & 1.863 \\
Profitability & 3833 & 0.050 & 0.055 & 0.074 \\
Tobin's Q & 3598 & 1.210 & 1.141 & 0.459 \\
Leverage & 3836 & 0.525 & 0.535 & 0.189 \\
Cash & 3836 & 0.072 & 0.048 & 0.082 \\
Log(GDP per capita) & 4621 & 10.453 & 10.770 & 0.844 \\
Inflation & 4621 & 2.355 & 2.109 & 1.912 \\
\hline
\end{tabular}

This table presents descriptive statistics. Reported are the number of observations (N), mean value, median, and standard deviation (SD). A detailed description of all variables can be found in Appendix A. 
Table 3: How does extreme weather affect investments in power plants?

\begin{tabular}{|c|c|c|c|c|}
\hline \multicolumn{5}{|c|}{ Panel A: investments in flexible power plants } \\
\hline Column & 1 & 2 & 3 & 4 \\
\hline Extreme weather $_{t-1}$ & $\begin{array}{c}0.87 * * * \\
(3.34)\end{array}$ & $\begin{array}{c}0.51 * * * \\
(4.05)\end{array}$ & $\begin{array}{c}0.55 * * * \\
(3.32)\end{array}$ & $\begin{array}{c}0.52^{* *} \\
(2.24)\end{array}$ \\
\hline $\log (\text { assets })_{t-1}$ & & & $\begin{array}{c}0.021^{*} \\
(1.75)\end{array}$ & $\mathrm{n} / \mathrm{a}$ \\
\hline Profitability $_{t-1}$ & & & $\begin{array}{l}-0.034 \\
(-1.21)\end{array}$ & $\mathrm{n} / \mathrm{a}$ \\
\hline Tobin's $Q_{t-1}$ & & & $\begin{array}{c}0.024^{* * *} \\
(3.65)\end{array}$ & $\mathrm{n} / \mathrm{a}$ \\
\hline Leverage $_{t-1}$ & & & $\begin{array}{l}-0.040 \\
(-0.91)\end{array}$ & $\mathrm{n} / \mathrm{a}$ \\
\hline $\operatorname{Cash}_{t-1}$ & & & $\begin{array}{c}0.11 \\
(1.66)\end{array}$ & $\mathrm{n} / \mathrm{a}$ \\
\hline Log(GDP per capita $t-1)$ & & & $\begin{array}{c}0.33 \\
(1.53)\end{array}$ & $\begin{array}{l}0.33^{*} \\
(1.70)\end{array}$ \\
\hline Inflation $_{t-1}$ & & & $\begin{array}{c}-0.0013 \\
(-0.62)\end{array}$ & $\begin{array}{l}0.013^{*} \\
(2.02)\end{array}$ \\
\hline Year-FE & yes & yes & yes & yes \\
\hline Region-FE & no & yes & yes & yes \\
\hline Firm-FE & no & yes & yes & yes \\
\hline Firm x region-FE & no & yes & yes & yes \\
\hline Firm x year-FE & no & no & no & yes \\
\hline Observations & 4,978 & 4,931 & 3,850 & 2,926 \\
\hline Adj. $R^{2}$ & 0.012 & 0.56 & 0.57 & 0.60 \\
\hline \multicolumn{5}{|c|}{ Panel B: investments in other power plants } \\
\hline Column & $\begin{array}{c}1 \\
\text { inflex }\end{array}$ & $\begin{array}{c}2 \\
\text { renew }\end{array}$ & tot & 4 \\
\hline Extreme weather ${ }_{t-1}$ & $\begin{array}{l}-0.025 \\
(-0.34)\end{array}$ & $\begin{array}{l}-0.099 \\
(-1.58)\end{array}$ & $\begin{array}{c}0.45^{* * *} \\
(2.86)\end{array}$ & $\begin{array}{c}0.53^{* *} \\
(2.71)\end{array}$ \\
\hline Controls & no & no & no & yes \\
\hline Year-FE & yes & yes & yes & yes \\
\hline Region-FE & yes & yes & yes & yes \\
\hline Firm-FE & yes & yes & yes & yes \\
\hline Firm $x$ region-FE & yes & yes & yes & yes \\
\hline Observations & 4,931 & 4,931 & 4,931 & 3,850 \\
\hline Adj. $R^{2}$ & 0.71 & 0.51 & 0.62 & 0.65 \\
\hline
\end{tabular}


Table 3 continued

The dependent variable in Panel A is FLexiBle investment, which is defined as early-stage flexible power plant construction projects (in megawatt, MW) of firm $i$ in region $j$ (and year $t$ ), scaled by the capacity of existing power plants (in MW) of the same firm $i$ in the same region $j$ (and year $t$ ). Gas, oil, and pump storage power plants are classified as flexible plants. The dependent variables in Panel B are inflexible investment, renewable investment, and total investment. The non-reported control variables follow those in Panel A. Extreme weather is the fraction of days with an extreme temperature in a particular year and electricity market. A day is classified as extreme if its temperature would belong to the $1 \%$ hottest or coolest days during the base period 1951 to 1980 . Tstatistics based on robust standard errors clustered by regions and firms are presented in parentheses. $* * *, * *$ and $*$ indicate significance on the $1 \%-, 5 \%$ - and 10\%-levels, respectively. A detailed description of all variables can be found in Appendix A. 
Table 4: Robustness tests I/II: market power and input prices

\begin{tabular}{|c|c|c|c|c|}
\hline \multicolumn{5}{|l|}{ Panel A: market power } \\
\hline Column & 1 & 2 & 3 & 4 \\
\hline Market share (capacity) & $<20 \%$ & $<10 \%$ & $<1 \%$ & all \\
\hline Extreme weather ${ }_{t-1}$ & $\begin{array}{c}0.51 * * * \\
(3.99)\end{array}$ & $\begin{array}{c}0.36 * * * \\
(3.73)\end{array}$ & $\begin{array}{c}0.58 * * * \\
(3.66)\end{array}$ & $\begin{array}{c}0.57^{* * *} \\
(3.66)\end{array}$ \\
\hline Market share (capacity) & & & & $\begin{array}{l}-0.075 \\
(-1.23)\end{array}$ \\
\hline Extreme weather $_{t-1} \times$ market share & & & & $\begin{array}{c}-0.30 \\
(-0.58)\end{array}$ \\
\hline Year-FE & yes & yes & yes & yes \\
\hline Firm $\mathrm{x}$ region-FE & yes & yes & yes & yes \\
\hline Observations & 3,663 & 2,916 & 1,386 & 4,921 \\
\hline Adj. $R^{2}$ & 0.60 & 0.65 & 0.71 & 0.56 \\
\hline \multicolumn{5}{|l|}{ Panel B: spark spread and gas price } \\
\hline Column & 1 & 2 & 3 & 4 \\
\hline Extreme weather ${ }_{t-1}$ & $\begin{array}{c}0.42^{* * *} \\
(3.91)\end{array}$ & $\begin{array}{c}0.41 * * * \\
(4.09)\end{array}$ & $\begin{array}{c}0.31 * * \\
(2.81)\end{array}$ & $\begin{array}{c}0.28^{* *} \\
(2.44)\end{array}$ \\
\hline Gas price $_{t-1}$ & $\begin{array}{c}-0.00059 \\
(-0.51)\end{array}$ & $\begin{array}{c}-0.00064 \\
(-0.56)\end{array}$ & & \\
\hline Extreme weather ${ }_{t-1} \mathrm{x}$ gas price $t-1$ & & $\begin{array}{c}0.0014 \\
(0.14)\end{array}$ & & \\
\hline Spark spread ${ }_{t-1}$ & & & $\begin{array}{c}0.00093^{* *} \\
(2.50)\end{array}$ & $\begin{array}{c}0.00074^{* *} \\
(2.55)\end{array}$ \\
\hline Extreme weather $_{t-1}$ x spark spread $t_{t-1}$ & & & & $\begin{array}{c}0.0079 \\
(1.32)\end{array}$ \\
\hline Year-FE & yes & yes & yes & yes \\
\hline Firm $\mathrm{x}$ region-FE & yes & yes & yes & yes \\
\hline Observations & 3,754 & 3,754 & 3,241 & 3,241 \\
\hline Adj. $R^{2}$ & 0.60 & 0.60 & 0.61 & 0.61 \\
\hline
\end{tabular}


Table 4 continued

The baseline specification is as follows: the dependent variable is flexible investment, which is defined as early-stage flexible power plant construction projects (in megawatt, MW) of firm $i$ in region $j$ (and year $t$ ), scaled by the capacity of existing power plants (in MW) of the same firm $i$ in the same region $j$ (and year $t$ ). Gas and oil-fired power plants are classified as flexible plants. Extreme weather is the fraction of days with an extreme temperature in a particular year and electricity market. A day is classified as extreme if its temperature would belong to the $1 \%$ hottest or coolest days during the base period 1951 to 1980 . T-statistics based on robust standard errors clustered by regions and firms are presented in parentheses.

In Panel A, Columns 1 to 3, only firms that account for less than 20\%, 10\%, or $1 \%$ of the production capacity in a particular market and year are considered. In Column 4, we interact firms' market share in terms of capacity with extreme weather. Panel B controls for the gas price and the spark spread. The spark spread is the difference between the wholesale price of electricity and the cost of producing electricity using natural gas (we assume an efficiency of $50 \%$ of gas-fired power plants for its calculation). Gas prices come from the EIA for U.S. states and the IEA for all other countries.

$* * *, * *$ and $*$ indicate significance on the 1\%-, 5\%- and $10 \%$-levels, respectively. A detailed description of all variables can be found in Appendix A. 
Table 5: Mechanism: how does extreme weather affect electricity?

\begin{tabular}{|c|c|c|c|c|}
\hline \multicolumn{5}{|c|}{ Panel A: weather characteristics } \\
\hline Column & 1 & 2 & 3 & 4 \\
\hline Sample & \multicolumn{4}{|c|}{ region-year-level } \\
\hline Dependent & CDD & HDD & weather vol & $\log ($ weather vol $)$ \\
\hline Extreme weather $r_{t-1}$ & $\begin{array}{c}1,714^{* * *} \\
(4.63) \\
\end{array}$ & $\begin{array}{c}1,175^{* * *} \\
(2.99) \\
\end{array}$ & $\begin{array}{c}14.0 * * * \\
(8.51)\end{array}$ & $\begin{array}{c}2.33^{* * *} \\
(8.72)\end{array}$ \\
\hline Controls & no & no & no & no \\
\hline Year-FE & yes & yes & yes & yes \\
\hline Region-FE & yes & yes & yes & yes \\
\hline Observations & 570 & 570 & 570 & 570 \\
\hline Adj. $R^{2}$ & 0.99 & 0.98 & 0.97 & 0.98 \\
\hline \multicolumn{5}{|c|}{ Panel B: electricity demand } \\
\hline Column & 1 & 2 & 3 & 4 \\
\hline Sample & \multicolumn{4}{|c|}{ region-year-level (U.S. only) } \\
\hline Dependent & $\log ($ residential $)$ & $\log ($ total $)$ & $\operatorname{vol}($ demand $)$ & $\log ($ demand vol $)$ \\
\hline Extreme weather $_{t-1}$ & $\begin{array}{l}0.50^{* *} \\
(2.45) \\
\end{array}$ & $\begin{array}{c}0.23 \\
(0.90) \\
\end{array}$ & $\begin{array}{l}0.45^{* *} \\
(3.70) \\
\end{array}$ & $\begin{array}{l}3.02^{* *} \\
(2.89) \\
\end{array}$ \\
\hline Controls & no & no & no & no \\
\hline Year-FE & yes & yes & yes & yes \\
\hline Region-FE & yes & yes & yes & yes \\
\hline Observations & 489 & 451 & 488 & 450 \\
\hline Adj. $R^{2}$ & 0.70 & 0.74 & 0.71 & 0.72 \\
\hline \multicolumn{5}{|c|}{ Panel C: electricity price characteristics } \\
\hline Column & 1 & 2 & 3 & 4 \\
\hline Sample & \multicolumn{4}{|c|}{ region-year-level } \\
\hline Dependent & \multicolumn{2}{|c|}{$\log ($ electricity price $)$} & \multicolumn{2}{|c|}{$\log ($ price volatility $)$} \\
\hline Extreme weather ${ }_{t-1}$ & $\begin{array}{c}0.80 \\
(1.05)\end{array}$ & $\begin{array}{c}1.12 \\
(1.67)\end{array}$ & $\begin{array}{l}3.08^{* *} \\
(2.56)\end{array}$ & $\begin{array}{c}3.62^{* * *} \\
(3.03)\end{array}$ \\
\hline Controls & no & yes & no & yes \\
\hline Year-FE & yes & yes & yes & yes \\
\hline Region-FE & yes & yes & yes & yes \\
\hline Observations & 489 & 451 & 488 & 450 \\
\hline Adj. $R^{2}$ & 0.70 & 0.74 & 0.71 & 0.72 \\
\hline
\end{tabular}

continued on next page 
Table 5 continued

\begin{tabular}{lcccc}
\hline \multicolumn{4}{l}{ Panel D: price characteristics and flexible investments } \\
\hline Column & 1 & 2 & 3 & 4 \\
Sample & \multicolumn{4}{c}{$\begin{array}{c}\text { firm-region-year-level } \\
\text { flexible investment }\end{array}$} \\
Dependent & \multicolumn{4}{c}{-0.018} \\
\hline Log(electricity price $t-1)$ & 0.018 & $(-0.52)$ & -0.026 \\
& $(0.56)$ & $0.035^{* * *}$ & $0.039^{* * *}$ & $0.037^{* * *}$ \\
Log(price volatility $t-1)$ & & $(4.63)$ & $(4.27)$ & $(4.70)$ \\
& & no & no & yes \\
Controls & no & yes & yes & yes \\
Year-FE & yes & yes & yes & yes \\
Region-FE & yes & 4,072 & 4,072 & 3,172 \\
Observations & 4,090 & 0.58 & 0.58 & 0.58 \\
Adj. R & 0.57 & & \\
\hline
\end{tabular}

Panel A explores how extreme weather affects other weather-related aspects. These are cooling degree days (CDD) in Column 1, heating degree days (HDD) in Column 2, the volatility of the daily temperatures in Column 3, and the logarithm of this volatility in Column 4 . Extreme weather is the fraction of days with an extreme temperature in a particular year and electricity market. A day is classified as extreme if its temperature would belong to the $1 \%$ hottest or coolest days during the base period 1951 to 1980 .

Panel B focuses on the impact of extreme weather on electricity demand. This panel is estimated only for U.S. electricity markets because monthly generation data is not available elsewhere. The logarithm of residential consumption is the dependent variable in Column 1, the logarithm of total consumption in Column 2, the standard deviation of the total generation (which approx. equals demand in a market/year), standardized by the average consumption in that market, in Column 3, and the logarithm of this standard deviation in Column 4.

Panel $\mathrm{C}$ analyzes how extreme weather affects electricity price characteristics. These are the logarithm of the average electricity price in a market (and year) in Columns 1 and 2 and the standard deviation of hourly electricity prices, normalized by a market's average electricity price level, in Columns 3 and 4 . The non-reported regional control variables are GDP per capita and inflation. Panel D links the average electricity price and its volatility to investments in flexible power plants using the firm-region-year dataset. The non-reported control variables equal those in Column 3 of Table 3.

T-statistics based on robust standard errors clustered by regions (for region-year-level analyses) or regions and firms (for firm-region-year level analyses) are presented in parentheses. $* * *, * *$ and * indicate significance on the 1\%-, 5\%- and 10\%-levels, respectively. A detailed description of all variables can be found in Appendix A. 
Table 6: Do current realizations of extreme weather help to predict the future?

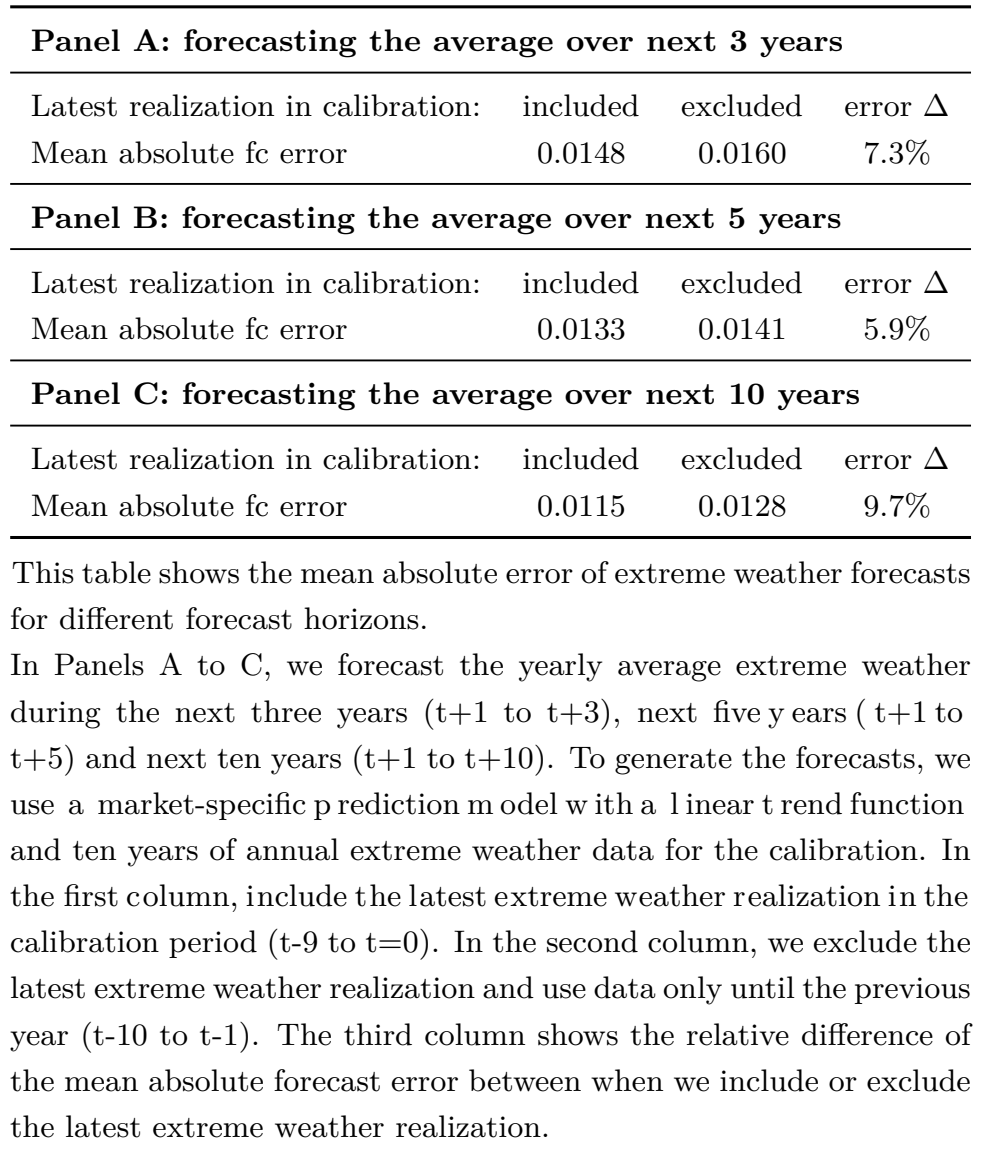


Table 7: Which role does operating flexibility play for investment decisions?

\begin{tabular}{|c|c|c|c|c|}
\hline \multicolumn{5}{|c|}{ Panel A: change in operating flexibility } \\
\hline \multirow[t]{2}{*}{ Column } & \multirow{2}{*}{\multicolumn{2}{|c|}{$\begin{array}{cc}1 & 2 \\
\text { planned change }\end{array}$}} & \multirow{2}{*}{\multicolumn{2}{|c|}{$\begin{array}{l}3 \\
\text { actual change }\end{array}$}} \\
\hline & & & & \\
\hline Extreme weather ${ }_{t-1}$ & $\begin{array}{c}0.78 * * * \\
(4.78)\end{array}$ & $\begin{array}{c}0.72^{* * *} \\
(4.10)\end{array}$ & $\begin{array}{c}0.74^{* *} \\
(2.55)\end{array}$ & $\begin{array}{c}0.92^{* *} \\
(2.31)\end{array}$ \\
\hline Controls & no & yes & no & yes \\
\hline Year-FE & yes & yes & yes & yes \\
\hline Region-FE & yes & yes & yes & yes \\
\hline Firm-FE & yes & yes & yes & yes \\
\hline Firm $\mathrm{x}$ region-FE & yes & yes & yes & yes \\
\hline Observations & 3,993 & 3,179 & 2,386 & 1,915 \\
\hline Adj. $R^{2}$ & 0.57 & 0.58 & 0.35 & 0.42 \\
\hline \multicolumn{5}{|c|}{ Panel B: existing operating flexibility and investments } \\
\hline \multirow[t]{2}{*}{ Column } & 1 & 2 & 3 & 4 \\
\hline & low flex & high flex & \multicolumn{2}{|c|}{ all } \\
\hline Extreme weather ${ }_{t-1}$ & $\begin{array}{c}0.84^{* * *} \\
(3.01)\end{array}$ & $\begin{array}{c}0.37 * * * \\
(3.56)\end{array}$ & $\begin{array}{c}1.38^{* * *} \\
(3.94)\end{array}$ & $\begin{array}{c}1.39^{* * *} \\
(3.27)\end{array}$ \\
\hline \multirow[t]{2}{*}{ Operating flex $t-1$} & & & -0.0033 & -0.020 \\
\hline & & & $(-0.061)$ & $(-0.34)$ \\
\hline \multirow[t]{2}{*}{ Extreme weather $_{t-1} \times$ OpFlex $_{t-1}$} & & & $-1.44^{* * *}$ & $-1.40 * * *$ \\
\hline & & & $(-3.47)$ & $(-2.90)$ \\
\hline Controls & no & no & no & yes \\
\hline Year-FE & yes & yes & yes & yes \\
\hline Region-FE & yes & yes & yes & yes \\
\hline Firm-FE & yes & yes & yes & yes \\
\hline Firm $\mathrm{x}$ region-FE & yes & yes & yes & yes \\
\hline Observations & 2,266 & 2,266 & 4,572 & 3,609 \\
\hline Adj. $R^{2}$ & 0.60 & 0.57 & 0.56 & 0.58 \\
\hline
\end{tabular}

The dependent variables in Panel A are planned flexibility change and actual flexibility change. Planned flexibility change is calculated as current plus planned capacity of flexible power plants, relative to current capacity flexible power plants. Actual flexibility change is the relative change of the capacity of flexible power plants between year $t$ and year $t+4$. In Panel B, the dependent variable is flexible investment. Operating flexibility is the ratio of flexible production capacity to flexible plus inflexible production capacity.

Extreme weather is the fraction of days with an extreme temperature in a particular year and electricity market. A day is classified as extreme if its temperature would belong to the $1 \%$ hottest or coolest days during the base period 1951 to 1980 . The non-reported control variables equal those in Column 3 of Table 3 .

T-statistics based on robust standard errors clustered by regions and firms are presented in parentheses. ${ }^{* * *}, * *$ and $*$ indicate significance on the $1 \%-, 5 \%$ - and $10 \%$-levels, respectively. A detailed description of all variables can be found in Appendix A. 
Table 8: Which role does the forecastability of weather play for investment decisions?

\begin{tabular}{|c|c|c|c|c|}
\hline \multicolumn{5}{|c|}{ Panel A: average absolute forecast error } \\
\hline Column & 1 & 2 & 3 & 4 \\
\hline Sample & low & high & \multicolumn{2}{|c|}{ all } \\
\hline Extreme weather $_{t-1}$ & $\begin{array}{c}0.34^{*} \\
(1.97)\end{array}$ & $\begin{array}{c}0.65 * * \\
(2.90)\end{array}$ & $\begin{array}{c}0.28^{* *} \\
(2.50)\end{array}$ & $\begin{array}{c}0.22^{*} \\
(1.86)\end{array}$ \\
\hline Forecast error ${ }_{t-1}$ & & & $\begin{array}{l}-0.018 \\
(-0.48)\end{array}$ & $\begin{array}{r}-0.0097 \\
(-0.21)\end{array}$ \\
\hline Extreme weather $_{t-1} \times$ fc error er-1 $_{t}$ & & & $\begin{array}{c}1.35^{* *} \\
(2.13)\end{array}$ & $\begin{array}{c}1.50 * * \\
(2.15)\end{array}$ \\
\hline Controls & no & no & no & yes \\
\hline Year-FE & yes & yes & yes & yes \\
\hline Firm $\mathrm{x}$ region-FE & yes & yes & yes & yes \\
\hline Observations & 1,161 & 1,202 & 2,478 & 1,966 \\
\hline Adj. $R^{2}$ & 0.74 & 0.77 & 0.76 & 0.74 \\
\hline
\end{tabular}

Panel B: dispersion of weather forecasts by different providers

\begin{tabular}{|c|c|c|c|c|}
\hline $\begin{array}{l}\text { Column } \\
\text { Sample }\end{array}$ & $\begin{array}{c}1 \\
\text { low }\end{array}$ & $\begin{array}{c}2 \\
\text { high }\end{array}$ & \multicolumn{2}{|c|}{ all } \\
\hline Extreme weather ${ }_{t-1}$ & $\begin{array}{c}0.21 \\
(1.09)\end{array}$ & $\begin{array}{c}0.63 * * \\
(2.52)\end{array}$ & $\begin{array}{c}0.19^{* *} \\
(2.20)\end{array}$ & $\begin{array}{c}0.15 \\
(1.52)\end{array}$ \\
\hline Forecast dispersion $_{t-1}$ & & & $\begin{array}{l}-0.057 \\
(-1.27)\end{array}$ & $\begin{array}{l}-0.044 \\
(-1.19)\end{array}$ \\
\hline 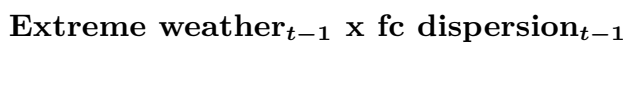 & & & $\begin{array}{c}3.00 * * \\
(2.48)\end{array}$ & $\begin{array}{c}2.91 * * * \\
(2.89)\end{array}$ \\
\hline Year-FE & yes & yes & yes & yes \\
\hline Firm $\mathrm{x}$ region-FE & yes & yes & yes & yes \\
\hline Observations & 1,156 & 1,169 & 2,478 & 1,966 \\
\hline Adj. $R^{2}$ & 0.70 & 0.76 & 0.76 & 0.75 \\
\hline
\end{tabular}


Table 8 continued

The dependent variable is flexible investment, which is defined as early-stage flexible power plant construction projects (in megawatt, MW) of firm $i$ in region $j$ (and year $t$ ), scaled by the capacity of existing power plants (in MW) of the same firm $i$ in the same region $j$ (and year $t$ ). Gas, oil, and pump storage power plants are classified as flexible plants. Extreme weather is the fraction of days with an extreme temperature in a particular year and electricity market. A day is classified as extreme if its temperature would belong to the $1 \%$ hottest or coolest days during the base period 1951 to 1980 . The non-reported control variables equal those in Column 3 of Table 3 .

Weather forecast data obtained from ForecastWatch is available for the U.S. from 2005, for Canada from 2007, and for most other countries from 2012. Temperature forecasts from multiple providers are included. Forecast error is the absolute difference between the average 3-day temperature forecast across all providers and the actual temperature on that day. Forecast dispersion is the interquartile range of the 3-day temperature forecasts from all forecast providers for that day.

T-statistics based on robust standard errors clustered by regions and firms are presented in parentheses. $* * *, * *$ and * indicate significance on the $1 \%$-, 5\%- and $10 \%$-levels, respectively. A detailed description of all variables can be found in Appendix A. 


\section{Appendix}

Appendix A: Definition of variables

\begin{tabular}{|c|c|}
\hline Variable & Description \\
\hline \multicolumn{2}{|l|}{ Investment variables } \\
\hline Flexible investment & $\begin{array}{l}\text { Planned flexible power plant construction projects (in megawatt, MW) of } \\
\text { firm } i \text { in region } j \text { and year } t \text {, scaled by the capacity of existing power plants } \\
\text { (in MW) of the same firm } i \text { in the same region } j \text { and year } t \text {. The variable } \\
\text { is set to one if planned flexible investments exceeds total installed capacity. } \\
\text { Gas, oil, and pump storage plants are classified as flexible plants. Source: } \\
\text { Own calculations based on Platts WEPP data. }\end{array}$ \\
\hline Inflexible inv. & $\begin{array}{l}\text { The construction follows the flexible investment variable. Inflexible power } \\
\text { plants are coal and nuclear power plants. }\end{array}$ \\
\hline Renewable inv. & $\begin{array}{l}\text { The construction follows the flexible investment variable. Renewable power } \\
\text { plants are solar and wind plants. }\end{array}$ \\
\hline Total investment & $\begin{array}{l}\text { The construction follows the flexible investment variable. All planned power } \\
\text { plants are considered. }\end{array}$ \\
\hline \multicolumn{2}{|l|}{ Weather variables } \\
\hline Extreme weather & $\begin{array}{l}\text { Extreme weather is the fraction of days with an extreme temperature in a } \\
\text { particular year and electricity market. A day is classified as extreme if its } \\
\text { temperature would belong to the } 1 \% \text { hottest or coolest days during the base } \\
\text { period } 1951 \text { to } 1980 \text {. In the absence of climatic changes, we would expect } \\
\text { to classify one percent of days as extremely hot and one percent of day as } \\
\text { extremely cold during our sample period, which leads to an expected value } \\
\text { for this variable of two percent. Source: Own calculations based on GHCN } \\
\text { data. }\end{array}$ \\
\hline Extreme weather ${ }^{0.5 \%}$ & $\begin{array}{l}\text { The construction follows the extreme weather variable, but uses the } 0.5 \% \text { of } \\
\text { hottest and coolest days during the base period. }\end{array}$ \\
\hline Extreme weather ${ }^{5 \%}$ & $\begin{array}{l}\text { The construction follows the extreme weather variable, but uses the } 5 \% \text { of } \\
\text { hottest and coolest days during the base period. }\end{array}$ \\
\hline $\begin{array}{l}\text { Extreme } \\
\text { weather }{ }^{1 \%, \text { weekly }}\end{array}$ & $\begin{array}{l}\text { The construction follows the extreme weather variable, but uses weekly in- } \\
\text { stead of daily temperatures. }\end{array}$ \\
\hline $\begin{array}{l}\text { Extreme } \\
\text { weather }{ }^{1 \%, \text { hottest }}\end{array}$ & $\begin{array}{l}\text { The construction follows the extreme weather variable, but uses only ex- } \\
\text { tremely hot days. }\end{array}$ \\
\hline Weather volatility & Standard deviation of daily average temperatures in a market and year. \\
\hline Weather forecast error & $\begin{array}{l}\text { Absolute difference between the average } 3 \text {-day temperature forecast across } \\
\text { all providers and the actual temperature on that day. Forecast data from } \\
\text { multiple forecast providers is available for the U.S. from } 2005 \text {, for Canada } \\
\text { from } 2007 \text {, and for most other countries from } 2012 \text {. Source: Own calculations } \\
\text { based on ForecastWatch data. }\end{array}$ \\
\hline Weather fc dispersion & $\begin{array}{l}\text { Interquartile range of the } 3 \text {-day temperature forecasts from all forecast } \\
\text { providers for that day. }\end{array}$ \\
\hline
\end{tabular}


Definition of Variables - continued

\begin{tabular}{|c|c|}
\hline Variable & Description \\
\hline \multicolumn{2}{|l|}{ Electricity variables } \\
\hline Electricity price & $\begin{array}{l}\text { Average wholesale market price of electricity in a market and year based on } \\
\text { hourly prices. Electricity prices are in US\$ per megawatt hour (MWh). Local } \\
\text { electricity prices are converted to US\$ using daily exchange rates. Source: } \\
\text { Own calculations based on hourly electricity prices. }\end{array}$ \\
\hline Electricity price vol. & $\begin{array}{l}\text { Standard deviation of hourly electricity prices in a market and year, normal- } \\
\text { ized by the market's average electricity price level. Source: Own calculations } \\
\text { based on hourly electricity prices. }\end{array}$ \\
\hline CDD & $\begin{array}{l}\text { Cooling degree days. Calculated as the yearly sum of daily cooling degrees. } \\
\text { Cooling degrees is the number of degrees Celsius by which the daily average } \\
\text { temperature exceeds the base temperature of } 18.3 \text { degree Celsius. }\end{array}$ \\
\hline HDD & $\begin{array}{l}\text { Heating degree days. Calculated as the yearly sum of daily heating degrees. } \\
\text { Heating degrees is the number of degrees Celsius by which the daily average } \\
\text { temperature is below the base temperature of } 15.5 \text { degree Celsius. }\end{array}$ \\
\hline Residential demand & $\begin{array}{l}\text { Electricity sales to residential consumers in MWh per market and year. } \\
\text { Source: EIA. }\end{array}$ \\
\hline Total demand & Total electricity sales in MWh per market and year. Source: EIA. \\
\hline Vol(demand) & $\begin{array}{l}\text { Standard deviation of the monthly electricity generation in a market and } \\
\text { year, normalized by the market's average generation. Source: Own calcula- } \\
\text { tions based on EIA data. }\end{array}$ \\
\hline \multicolumn{2}{|l|}{ Other variables } \\
\hline Market share & $\begin{array}{l}\text { Generation capacity of of firm } i \text { in region } j \text { and year } t \text {, scaled by the total in- } \\
\text { stalled production capacity in region } j \text { and year } t \text {. Source: Own calculations } \\
\text { based on Platts WEPP data. }\end{array}$ \\
\hline Operating flexibility & $\begin{array}{l}\text { Flexible production capacity scaled by the sum of flexible and inflexible pro- } \\
\text { duction capacity. Source: Own calculations based on Platts WEPP data. }\end{array}$ \\
\hline Gas price & $\begin{array}{l}\text { Price of natural gas in US } \$ \text { per MWh. Source: EIA for U.S. states and IEA } \\
\text { for all other countries. }\end{array}$ \\
\hline Spark spread & $\begin{array}{l}\text { Difference between the wholesale price of electricity and the cost of producing } \\
\text { electricity using natural gas. Calculated as electricity price in US } \$ \text { per MWh } \\
\text { minus gas price in US } \$ \text { per MWh scaled by an efficiency factor of } 0.5 \text {. }\end{array}$ \\
\hline EPSI & Environmental policy stringency index for the energy sector. Source: OECD. \\
\hline $\begin{array}{l}\text { Renewable } \\
\text { penetration }\end{array}$ & $\begin{array}{l}\text { Wind and solar generation capacity in a market and year scaled by total } \\
\text { capacity. Source: Own calculations based on Platts WEPP data. }\end{array}$ \\
\hline Assets & Total assets [wc02999] in US\$. Source: Worldscope \\
\hline Profitability & Earnings before interest and taxes [wc18198] scaled by total assets. \\
\hline Tobin's Q & $\begin{array}{l}\text { Market capitalization of equity [wc08001] plus total liabilities [wc03351] } \\
\text { scaled by the sum of total liabilities plus book value of equity [wc03501]. }\end{array}$ \\
\hline Leverage & $\begin{array}{l}\text { Total debt [wc03255] scaled by the sum of total debt plus book value of } \\
\text { equity [wc03501]). }\end{array}$ \\
\hline Cash & Cash and short term investments [wc02001] scaled by total assets. \\
\hline GDP per capita & GDP per capita (in 2010 US\$) in a country and year. Source: Worldbank. \\
\hline Inflation & Yearly inflation rate in a country. Source: Worldbank. \\
\hline
\end{tabular}


Appendix B: Robustness tests II/II: alternative specifications

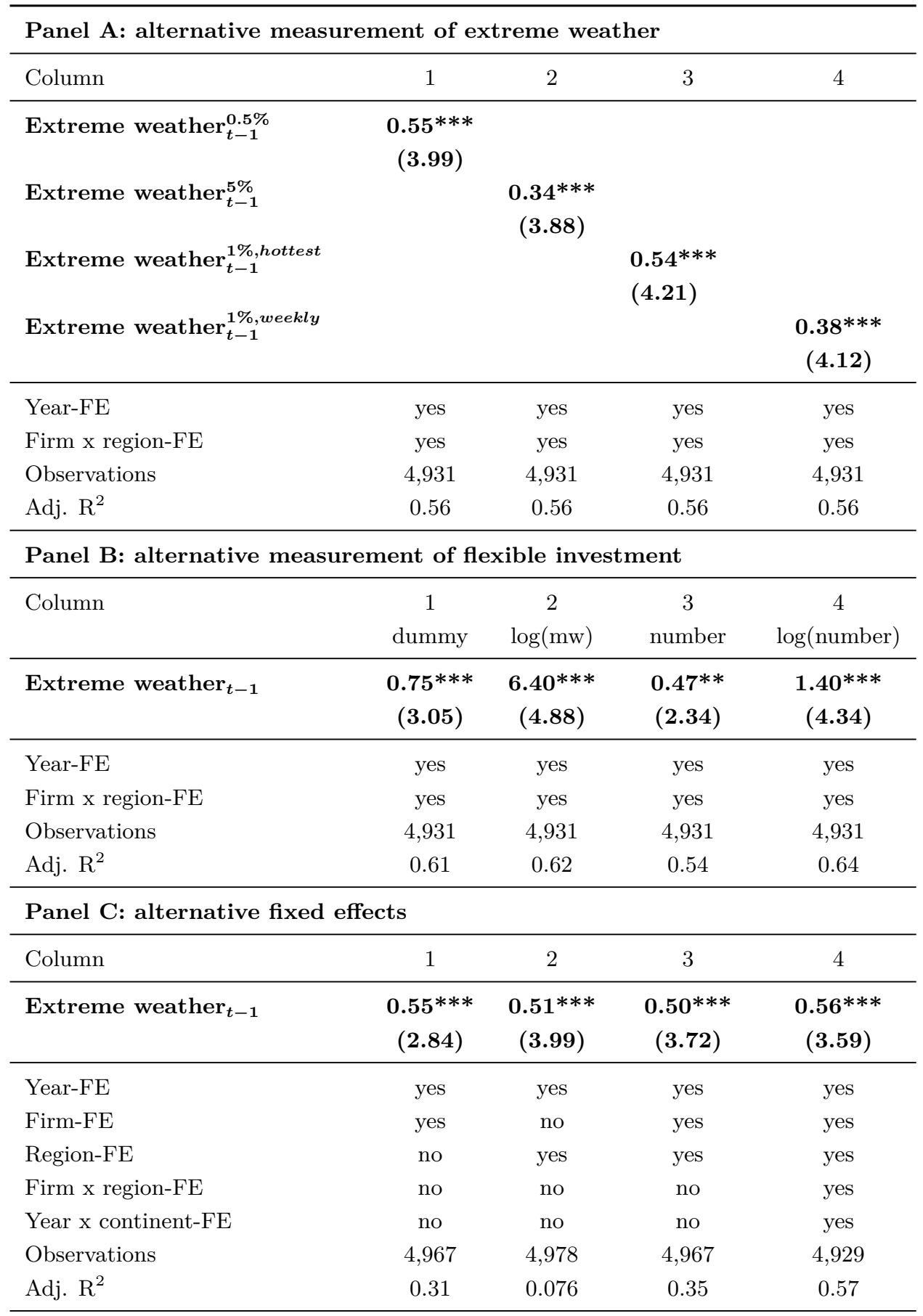

continued on next page 
Table Appendix B continued

\begin{tabular}{|c|c|c|c|c|}
\hline \multicolumn{5}{|c|}{ Panel D: alternative clustering of standard errors } \\
\hline Column & $\begin{array}{c}1 \\
\text { firm }\end{array}$ & $\begin{array}{c}2 \\
\text { region }\end{array}$ & $\begin{array}{c}3 \\
\text { region/year }\end{array}$ & $\begin{array}{c}4 \\
\mathrm{r} / \mathrm{y} / \mathrm{firm}\end{array}$ \\
\hline Extreme weather ${ }_{t-1}$ & $\begin{array}{c}0.51^{* * *} \\
(4.40)\end{array}$ & $\begin{array}{c}0.51^{* * *} \\
(4.03)\end{array}$ & $\begin{array}{c}0.51^{* * *} \\
(3.92)\end{array}$ & $\begin{array}{c}0.51 * * * \\
(3.95)\end{array}$ \\
\hline Year-FE & yes & yes & yes & yes \\
\hline Firm $\mathrm{x}$ region-FE & yes & yes & yes & yes \\
\hline Observations & 4,931 & 4,931 & 4,931 & 4,931 \\
\hline Adj. $R^{2}$ & 0.56 & 0.56 & 0.56 & 0.56 \\
\hline \multicolumn{5}{|c|}{ Panel E: further control variables } \\
\hline Column & 1 & 2 & 3 & 4 \\
\hline Extreme weather ${ }_{t-1}$ & $\begin{array}{c}0.56^{* * *} \\
(3.45)\end{array}$ & $\begin{array}{c}0.54 * * * \\
(3.17)\end{array}$ & $\begin{array}{c}0.57^{* * *} \\
(3.59)\end{array}$ & $\begin{array}{c}0.56^{* * *} \\
(3.28)\end{array}$ \\
\hline Stock market to $\mathrm{GDP}_{t-1}$ & $\begin{array}{c}0.00074^{*} \\
(1.92)\end{array}$ & & & $\begin{array}{c}-0.23^{* * *} \\
(-3.32)\end{array}$ \\
\hline Credit to $\mathrm{GDP}_{t-1}$ & $\begin{array}{c}-0.00072 \\
(-1.48)\end{array}$ & & & $\begin{array}{c}-0.40 \\
(-1.65)\end{array}$ \\
\hline $\log ($ market production capa $t-1)$ & & $\begin{array}{c}-0.29 * * * \\
(-3.83)\end{array}$ & & $\begin{array}{c}-0.12^{* * *} \\
(-11.5)\end{array}$ \\
\hline Market flexibility $t-1$ & & $\begin{array}{c}-0.27 \\
(-1.07)\end{array}$ & & $\begin{array}{c}0.00034 \\
(1.12)\end{array}$ \\
\hline Market age ${ }_{t-1}$ & & $\begin{array}{c}-0.065^{* * *} \\
(-4.28)\end{array}$ & & $\begin{array}{c}-0.00043 \\
(-1.05)\end{array}$ \\
\hline Log(firm production capa $t-1)$ & & & $\begin{array}{c}-0.070 * * * \\
(-5.07)\end{array}$ & $\begin{array}{c}-0.066^{* * *} \\
(-4.82)\end{array}$ \\
\hline Market fraction $_{t-1}$ & & & $\begin{array}{l}-0.053 \\
(-1.68)\end{array}$ & $\begin{array}{c}-0.053^{*} \\
(-1.75)\end{array}$ \\
\hline Year-FE & yes & yes & yes & yes \\
\hline Firm $\mathrm{x}$ region-FE & yes & yes & yes & yes \\
\hline Observations & 3,564 & 3,830 & 3,850 & 3,550 \\
\hline Adj. $R^{2}$ & 0.57 & 0.58 & 0.60 & 0.60 \\
\hline
\end{tabular}


The baseline specification is as follows: the dependent variable is flexible investment, which is defined as early-stage flexible power plant construction projects (in megawatt, MW) of firm $i$ in region $j$ (and year $t$ ), scaled by the capacity of existing power plants (in MW) of the same firm $i$ in the same region $j$ (and year $t$ ). Gas and oil-fired power plants are classified as flexible plants. Extreme weather is the fraction of days with an extreme temperature in a particular year and electricity market. A day is classified as extreme if its temperature would belong to the $1 \%$ hottest or coolest days during the base period 1951 to 1980 . T-statistics based on robust standard errors clustered by regions and firms are presented in parentheses.

In Panel A, alternative measure for extreme weather are used. Their exact definitions can be found in Appendix A. In Panel B, alternative proxies for flexible investments are used. In Column 1, we use a dummy variable which equals one if there is any investment in flexible plants in of firm $i$ in region $j$ (and year $t$ ), and zero otherwise. In Column 2 , the unscaled capacity of planned flexible power plants is used as dependent variable. The dependent variable in Column 3 is the number of planned flexible plants scaled by the number of existing plants. The logarithm of the unscaled number of plants is used as dependent variable in Column 4. In Panel C, we use alternative fixed effects. Panel D shows the results if we cluster standard errors by firm, region, region and year, or region and year and firm. Further control variables (in addition to those in Table 3) are included in Panel E.

$* * *, * *$ and $*$ indicate significance on the $1 \%-, 5 \%$ - and $10 \%$-levels, respectively. A detailed description of all variables can be found in Appendix A. 
Appendix C: Alternative mechanisms tests

\begin{tabular}{|c|c|c|c|c|}
\hline \multicolumn{5}{|c|}{ Panel A: renewable penetration in market } \\
\hline Column & 1 & 2 & 3 & 4 \\
\hline Sample & \multirow{2}{*}{\multicolumn{2}{|c|}{$\begin{array}{l}\text { region-year-level } \\
\text { renewable penetration }\end{array}$}} & \multirow{2}{*}{\multicolumn{2}{|c|}{$\begin{array}{c}\text { firm-region-year leve } \\
\text { flexible investment }\end{array}$}} \\
\hline Dependent & & & & \\
\hline \multirow[t]{2}{*}{ Extreme weather ${ }_{t-1}$} & -0.0075 & 0.00015 & & \\
\hline & $(-0.21)$ & $(0.0040)$ & & \\
\hline \multirow[t]{2}{*}{ Renewable penetration $_{t-1}$} & & & -0.050 & -0.046 \\
\hline & & & $(-0.19)$ & $(-0.18)$ \\
\hline Controls & no & yes & no & yes \\
\hline Year-FE & yes & yes & yes & yes \\
\hline Firm $\mathrm{x}$ region-FE & yes & yes & yes & yes \\
\hline Observations & 554 & 554 & 4,908 & 3,830 \\
\hline Adj. $R^{2}$ & 0.82 & 0.83 & 0.55 & 0.57 \\
\hline \multicolumn{5}{|c|}{ Panel B: environmental protection stringency } \\
\hline Column & 1 & 2 & 3 & 4 \\
\hline Sample & \multirow{2}{*}{\multicolumn{2}{|c|}{$\begin{array}{c}\text { region-year-level } \\
\text { EPSI }\end{array}$}} & \multirow{2}{*}{\multicolumn{2}{|c|}{$\begin{array}{c}\text { firm-region-year leve } \\
\text { flexible investment }\end{array}$}} \\
\hline Dependent & & & & \\
\hline \multirow[t]{2}{*}{ Extreme weather ${ }_{t-1}$} & 0.75 & 0.87 & & \\
\hline & $(0.61)$ & $(0.71)$ & & \\
\hline \multirow[t]{2}{*}{$\mathrm{EPSI}_{t-1}$} & & & 0.0020 & -0.0031 \\
\hline & & & $(0.18)$ & $(-0.26)$ \\
\hline Controls & no & yes & no & yes \\
\hline Year-FE & yes & yes & yes & yes \\
\hline Firm $\mathrm{x}$ region-FE & yes & yes & yes & yes \\
\hline Observations & 402 & 402 & 4,496 & 3,508 \\
\hline Adj. $R^{2}$ & 0.78 & 0.78 & 0.56 & 0.57 \\
\hline
\end{tabular}

The dependent variable is FLEXIBLE InVESTMENT, which is defined as earlystage flexible power plant construction projects (in megawatt, MW) of firm $i$ in region $j$ (and year $t$ ), scaled by the capacity of existing power plants (in MW) of the same firm $i$ in the same region $j$ (and year $t$ ). Gas, oil, and pump storage power plants are classified as flexible plants.

Renewable penetration is the generation capacity of wind and solar plants in a market and year, scaled by the market's total capacity. EPSI is the yearly environmental policy stringency index for the energy industry as published by the OECD. The non-reported controls for region-year level regressions are GDP per capita and inflation. The non-reported controls for the firm-region-year level regressions equal those in Column 3 of Table 3.

T-statistics based on robust standard errors clustered by regions (for regionyear-level analyses) or regions and firms (for firm-region-year level analyses) are presented in parentheses. $* * *, * *$ and $*$ indicate significance on the $1 \%$, $5 \%$ - and 10\%-levels, respectively. A detailed description of all variables can be found in Appendix A. 